NUREG/CR-6318

ORNL/TM-12937

\title{
Data Summary Report for Fission Product Release Test VI-7
}

Manuscript Completed: February 1995

Date Published: May 1995

Prepared by

M. F. Osborne, R. A. Lorenz, J. R. Travis, J. L. Collins, C. S. Webster

Oak Ridge National Laboratory

Managed by Martin Marietta Energy Systems, Inc.

Oak Ridge National Laboratory

Oak Ridge, TN 37831-6221

Prepared for

Division of Systems Research

Office of Nuclear Regulatory Research

U.S. Nuclear Regulatory Commission

Washington, DC 20555-0001

NRC Job Code L2250 
<smiles>[SiH3]</smiles> 


\section{DISCLAIMER}

This report was prepared as an account of work sponsored by an agency of the United States Government. Neither the United States Government nor any agency thereof, nor any of their employees, make any warranty, express or implied, or assumes any legal liability or responsibility for the accuracy, completeness, or usefulness of any information, apparatus, product, or process disclosed, or represents that its use would not infringe privately owned rights. Reference herein to any specific commercial product, process, or service by trade name, trademark, manufacturer, or otherwise does not necessarily constitute or imply its endorsement, recommendation, or favoring by the United States Government or any agency thereof. The views and opinions of authors expressed herein do not necessarily state or reflect those of the United States Government or any agency thereof. 


\section{DISCLAIMER}

Portions of this document may be illegible in electronic image products. Images are produced from the best available original document. 


\begin{abstract}
Test VI-7 was the seventh test in the VI series conducted in the vertical furnace. The fuel specimen was a $15.2-\mathrm{cm}$-long section of a fuel rod from the Monticello boiling water reactor (BWR). The fuel had experienced a burnup of $\sim 40 \mathrm{MWd} / \mathrm{kg} \mathrm{U}$, with inert gas ( $\mathrm{KI}$ and $\mathrm{Xe}$ ) release during irradiation of $-2 \%$. The fuel specimen was heated in an induction furnace for successive 20 -min periods at 2000 and $2300 \mathrm{~K}$ in a moist air-helium atmosphere. The released fission products were collected in three sequentially operated collection trains designed to facilitate sampling and analysis.

The fission product inventories in the fuel were measured directly by gamma-ray spectrometry, where possible, and were calculated by ORIGEN2. Integral releases were $69 \%$ for ${ }^{85} \mathrm{Kr}, 52 \%$ for ${ }^{125} \mathrm{Sb}, 71 \%$ for both ${ }^{134} \mathrm{Cs}$ and ${ }^{137} \mathrm{Cs}$, and $0.04 \%$ for ${ }^{154} \mathrm{Eu}$. For the non-gamma-emitting

species, release values of $42 \%$ for $\mathrm{I}, 4.1 \%$ for $\mathrm{Ba}, 5.3 \%$ for Mo, and $1.2 \%$ for Sr were determined. Of the totals released from the fuel, $10 \%$ of the Cs, $49 \%$ of the $\mathrm{Sb}$, and $98 \%$ of the Eu were deposited in the outlet end of the furnace. The total mass released from the furnace to the collection system, inciuding fission products, fuel, and structural materials, was $0.89 \mathrm{~g}$, with $37 \%$ being collected on the thermal gradient tubes and $63 \%$ downstream on filters. Examination of the thermal gradient tubes showed that large amounts of radiocesium were collected during all three phases of the test, but ${ }^{125} \mathrm{Sb}$ was collected on the thermal gradient tubes during Phase $\mathrm{C}$ only. Posttest examination of the fuel specimen indicated that most of the cladding was completely oxidized to $\mathrm{ZrO}_{3}$, but that oxidation was not quite complete at the upper end. The release behaviors for the most volatile elements, $\mathrm{Kr}$ and $\mathrm{Cs}$, were in good agreement with the ORNL Diffusion Model.
\end{abstract}





\section{Contents}

Abstract $\ldots \ldots \ldots \ldots \ldots \ldots \ldots \ldots \ldots \ldots \ldots \ldots \ldots \ldots \ldots \ldots \ldots \ldots \ldots$

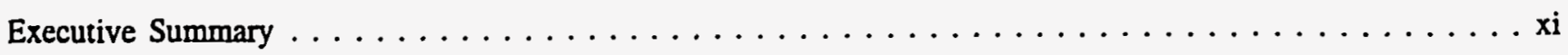

Foreword $\ldots \ldots \ldots \ldots \ldots \ldots \ldots \ldots \ldots \ldots \ldots \ldots \ldots \ldots \ldots \ldots \ldots \ldots \ldots \ldots$

1 Introduction $\ldots \ldots \ldots \ldots \ldots \ldots \ldots \ldots \ldots \ldots \ldots \ldots \ldots \ldots \ldots \ldots \ldots \ldots \ldots \ldots$

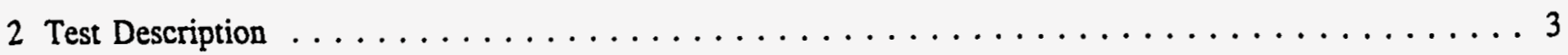

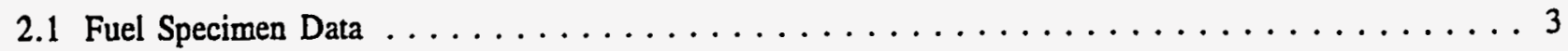

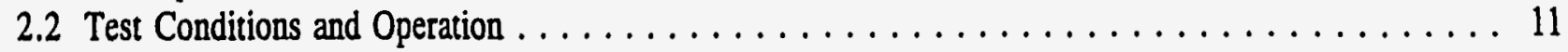

2.3 Posttest Disassembly and Examination $\ldots \ldots \ldots \ldots \ldots \ldots \ldots \ldots \ldots \ldots$

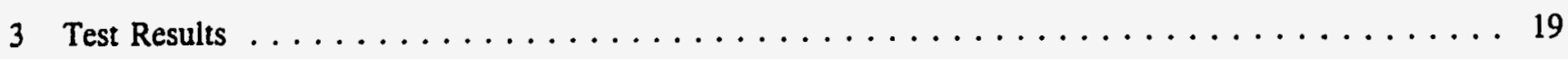

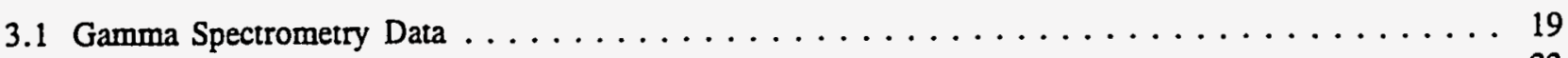

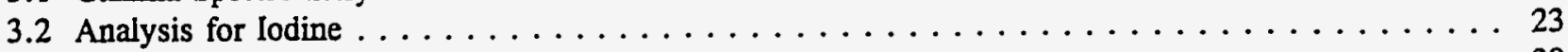

3.3 Thermal Gradient Tube Deposits . . . . . . . . . . . . . . . . . . . 29

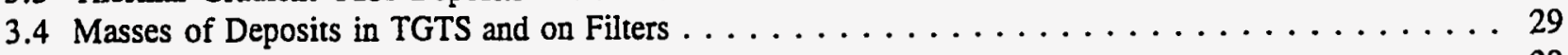

3.5 ICP-ES Analyses . . . . . . . . . . . . . . . . . . . . . . 29

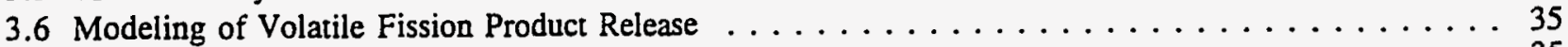

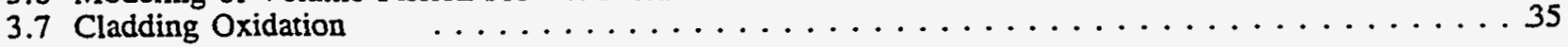

4 Comparison of Release Data with Previous Results $\ldots \ldots \ldots \ldots \ldots \ldots \ldots \ldots$

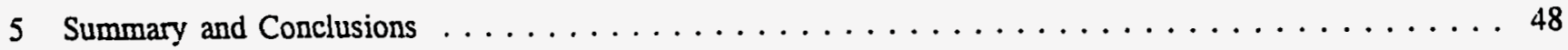

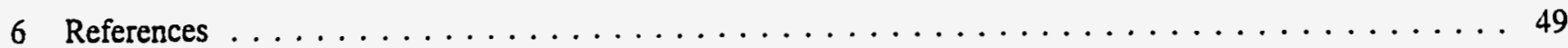





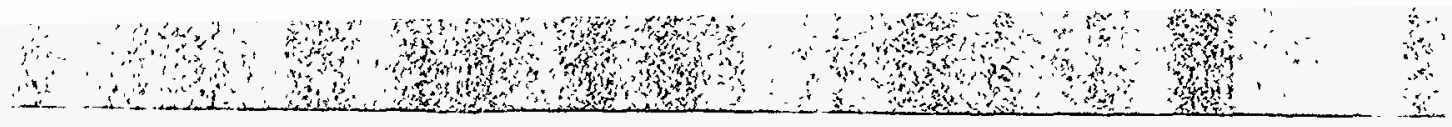

\section{Figures}

2.1 Vertical fission product release furnace, as used in test VI-6 $\ldots \ldots \ldots \ldots \ldots \ldots \ldots$

2.2 Vertical fission product release apparatus $\ldots \ldots \ldots \ldots \ldots \ldots \ldots \ldots \ldots \ldots \ldots$

2.3 Components of the fission product collection system $\ldots \ldots \ldots \ldots \ldots \ldots$

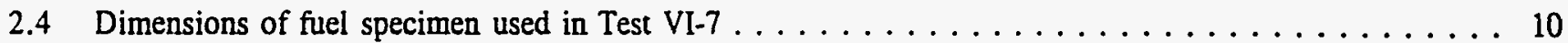

2.5 Axial distribution of ${ }^{134} \mathrm{Cs},{ }^{137} \mathrm{Cs},{ }^{125} \mathrm{Sb},{ }^{154} \mathrm{Eu}$, and ${ }^{60} \mathrm{Co}$ in Test VI-7 fuel specimen $\ldots \ldots \ldots 12$

2.6 Temperature history of Test VI-7 showing Test Phases A, B, and C . . . . . . . . . 14

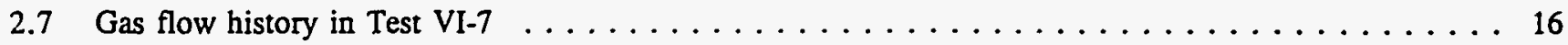

2.8 Release behavior of krypton and cesium in Test VI-7; cesium collected on TGTs was primarily vapor, and cesium collected on filters was primarily aerosol $\ldots \ldots \ldots \ldots \ldots \ldots \ldots \ldots$

3.1 Distribution of radionuclides in fuel specimen after Test VI-7. Note lower concentrations

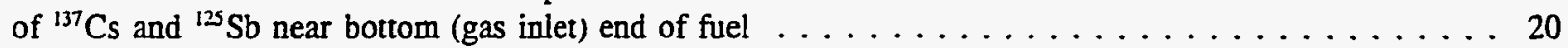

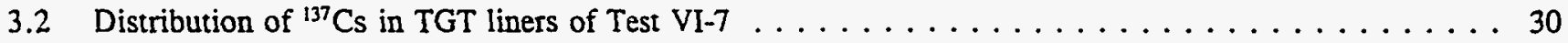

3.3 Distributions of ${ }^{137} \mathrm{Cs},{ }^{125} \mathrm{Sb}$, and ${ }^{60} \mathrm{Co}$ in TGT $\mathrm{C}$ liner of Test VI-7 $\ldots \ldots \ldots \ldots \ldots \ldots$

3.4 Mass distribution to the collection system of material released in Test VI-7 $\ldots \ldots \ldots \ldots$

3.5 Release rate coefficients for cesium in Test VI-7, plotted as a function of temperature. Note clusters of points at 200 and $2300 \mathrm{~K}$, the periods at constant temperature $\ldots \ldots \ldots \ldots \ldots$

3.6 Diffusion coefficients for cesium release in Test VI-7. Note clusters of points at 2000 and $2300 \mathrm{~K}$,

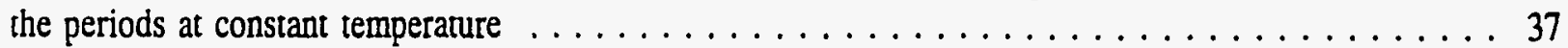

3.7 Cesium release rate coefficients for OR.VL VI tests. Note that values for Test VI-7 lie below CORSOR-M model and within the envelope of ORNL data $\ldots \ldots \ldots \ldots \ldots \ldots \ldots$

3.8 Successive oxidation protiles at test times of 60 to $85 \mathrm{~min}$ as calculated for Test VI-7 . . . . . . 39

3.9 Calculated extent of Zircaloy oxidation for selected locations in Test VI-7 $\ldots \ldots \ldots \ldots \ldots$

3.10 Fuel-cladding section from near the botom end of Test VI-7 showing uniformly oxidized

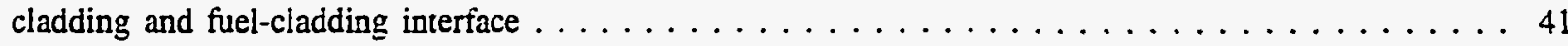

3.11 Radial section of cladding from near the top end of Test VI-7; note nonuniform oxidation, voids,

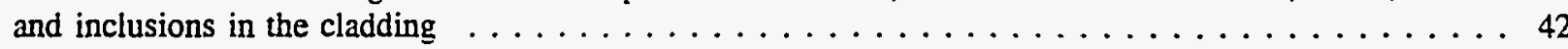

3.12 Radial section of cladding from near the top end of Test V1-7 showing bright phases of

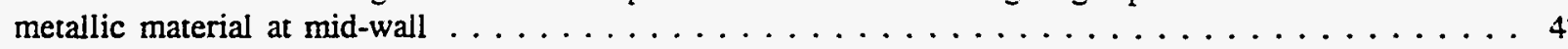





\section{Tables}

1.1 Analytical techniques used for fission product analysis $\ldots \ldots \ldots \ldots \ldots \ldots \ldots$

2.1 Data for fuel specimen used in Test VI-7 $\ldots \ldots \ldots \ldots \ldots \ldots \ldots \ldots \ldots \ldots$

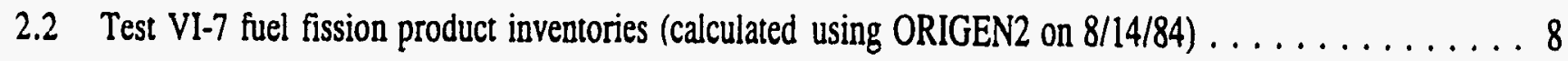

2.3 Test VI-7 fuel inventories and radioactivities (Monticello fuel, from ORIGEN2 calculation of 8/14/84) . . 9

2.4 Operating data for Test VI-7 $\ldots \ldots \ldots \ldots \ldots \ldots \ldots \ldots \ldots \ldots \ldots \ldots \ldots \ldots \ldots$

2.5 Chronology of Test VI-7, conducted September 16, 1993. Fuel specimen loaded into furnace

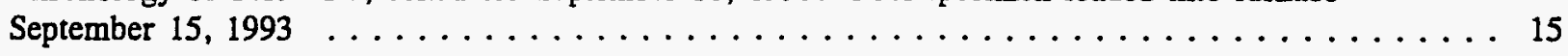

3.1 Summary of fission product release data for Test VI-7 $\ldots \ldots \ldots \ldots \ldots \ldots \ldots \ldots \ldots \ldots$

3.2 Cesium release and distribution data for Test VI-7 $\ldots \ldots \ldots \ldots \ldots \ldots \ldots \ldots$

3.3 Physical forms of cesium released from furnace in Test $\mathrm{VI}-7 \ldots \ldots \ldots \ldots \ldots \ldots \ldots$

3.4 Fractional releases and distributions of antimony and cobalt (from cladding) in Test VI-7 . . . . . 25

3.5 Fractional releases and distributions of iodine in Tests VI-6 and VI-7 $\ldots \ldots \ldots \ldots$

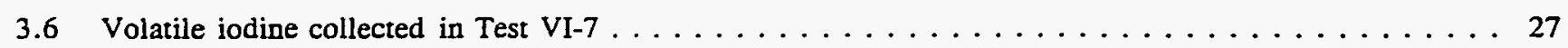

3.7 Comparison of physical forms of iodine and cesium released to collection trains in Test VI-7 . . . . 28

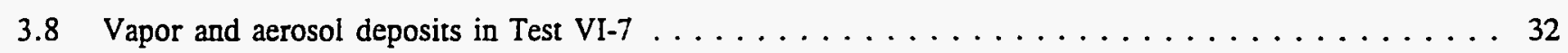

3.9 Release of low-volatility fission products in Test vI-7 $\ldots \ldots \ldots \ldots \ldots \ldots \ldots$

4.1 Conditions and results for vertical (VI series) fission product release tests $\ldots \ldots \ldots \ldots$

4.2 Mass release data for VI series tests $\ldots \ldots \ldots \ldots \ldots \ldots \ldots \ldots \ldots \ldots$ 



\section{Executive Summary}

The objective of this report is to document as completely as possible the observations and results of fission product release test VI-7. This report presents all currently available results for potential use by other reactor safety researchers. Complete interpretation and correlation of the results from earlier tests have been published, and similar data summary reports for previous tests in this project, as well as other reports of related project activities, are listed in the Foreword.

The 15-cm-long fuel specimen, irradiated to a burnup of $40.3 \mathrm{MWd} / \mathrm{kg} \mathrm{U}$ in the Monticello BWR, contained an initial loading of $112.3 \mathrm{~g}$ uranium enriched to $2.87 \%{ }^{235} \mathrm{U}$. The fission product inventories. as measured in the fuel and calculated by ORIGEN2, and a description of the test procedure and conditions are included in Section 2. The objective of Test VI-7 was to determine the effect of oxidation at high temperature by air and steam on fission product release and transport. Accordingly, the fuel specimen was heated to the test temperatures $(2000$ and $2300 \mathrm{~K}$ ) in a moist air-helium atmosphere. The test results and interpretations are presented in Section 3, and these results are compared with data from previous tests in Section 4 . The summary and conclusions of this test are included in Section 5, and the references are in Section 6 . The most important results are summarized below.

1. Although the Zircaloy cladding had been beavily oxidized during the test. the $15-\mathrm{cm}$-long ruel specimen had not collapsed but remained standing throughout the test.

2. The values for total fractional release from the fuel specimen, based on ORIGEN2 calculations and gamma ray spectrometry measurements. were $-69 \%$ for ${ }^{45} \mathrm{Kr}, 52 \%$ for ${ }^{125} \mathrm{Sb}, 71 \%$ for both ${ }^{134} \mathrm{Cs}$ and ${ }^{137} \mathrm{Cs}$, and $0.04 \%$ for ${ }^{154} \mathrm{Eu}$. Other measurement techniques showed that $42 \%$ of the I. $4.1 \%$ of the $\mathrm{Ba} .5 .3 \%$ of the Mo. and $1.2 \%$ of the $\mathrm{Sr}$ were released also. About $49 \%$ of the released $\because$ Sb. $10 \%$ of the released Cs, and $98 \%$ of the reieased
${ }^{154} \mathrm{Eu}$ were deposited on the $\mathrm{ZrO}_{2}$ ceramics at the outlet end of the fumace.

3. The axial distributions of the gamma-emitting fission products in the fuel, as well as the total inventories, were determined by gamma spectrometry. The release fractions from the fuel for ${ }^{125} \mathrm{Sb},{ }^{134} \mathrm{Cs}$, and ${ }^{137} \mathrm{Cs}$ were greatest at the bottom end of the specimen and declined with elevation. For ${ }^{154} \mathrm{Eu}$, however, for which there was minimal release, the axial distribution remained uniform. The varying releases of $\mathrm{Sb}$ and $\mathrm{Cs}$ are believed to be related to the extent of oxidation of the $\mathrm{UO}_{2}$.

4. The axial distributions of cesium in the thermal gradient tubes (TGTs) were relatively uniform, with the largest fraction in TGT A. Major peaks of radiocesium were located at 7 to $9 \mathrm{~cm}\left(-740^{\circ} \mathrm{C}\right)$ and 15 to $20 \mathrm{~cm}\left(-550\right.$ to $\left.450^{\circ} \mathrm{C}\right)$. No other radionuclides were detected in the TGTs except for small concentrations of ${ }^{125} \mathrm{Sb}$ and ${ }^{60} \mathrm{Co}$, both in TGT C.

5. The total mass of deposits on the TGTs and filters was determined by direct weighing to be $0.888 \mathrm{~g}$. Some $37 \%$ of this mass was collected on the TGTs, and the remaining $63 \%$ was found downstream on connecting tubes and filters, with $-61 \%$ of the total release occurring during Test Phase $\mathrm{C}$.

6. Approximately $0.5 \%$ of the released iodine $(0.33 \%$ of the total inventory in the fuel) was collected one of three volatile forms $-\mathrm{I}_{2}, \mathrm{HI}$, or $\mathrm{CH}_{3} \mathrm{I}$. This fraction of volatile iodine, which is believed to result from the reaction of stable forms such as CsI with impurities in the system, is similar to that observed in most previous tests.

7. The measured diffusion coefficients for the release of ${ }^{85} \mathrm{Kr}$ and ${ }^{137} \mathrm{Cs}$ agreed well with previous test results and with the ORNL Diffusion Release Model. 



\section{Foreword}

This document describes the seventh and final test in the VI series of fission product release tests of high-burnup, commercial LWR fuel under severe accident conditions at ORNL. Six similar tests were conducted in a simpler furnace at lower temperatures in the previous HI series. Other ORNL reports describing the work conducted for this project are listed below.

1. M. F. Osborne, R. A. Lorenz, J. R. Travis, and C. S. Webster, "Data Summary Report for Fission Product Release Test HI-1," NUREG/CR-2928 (ORNL/TM-8500), December 1982.

2. M. F. Osborne, R. A. Lorenz, J. R. Travis, C. S. Webster, and K. S. Norwood, "Dara Summary Report for Fission Product Release Test HI-2," NUREG/CR-3171 (ORNL/TM-8667), April 1984.

3. M. F. Osborne, R. A. Lorenz, K. S. Norwood, J. R. Travis, and C. S Webster, "Data Summary Report for Fission Product Release Test HI-3," NUREG/CR-3335 (ORNL/TM-8793), April 1984.

4. M. F. Osborne, J. L. Collins, R. A. Lorenz. K. S. Norwood. J. R. Travis, and C. S. Webster, "Data Summary Report for Fission Product Release Test HI-4," NUREG/CR-3600 (ORNL/ TM-9001), June 1984.

5. M. F. Osborne. J. L. Collins. R. A. Lorenz. K. S. Norwood. J. R. Travis, and C. S. Webster, "Data Summary Report for Fission Product Release Test HI-5," NUREG/CR-4037 (ORNLi TM1-9437), May 1985.

6. M. F. Osborne. J. L. Collins, R. A. Lorenz. K. S. Norwood, J. R. Travis, and C. S. Webster. "Data Summary Report for Fission Product Release Test HI-6," NUREG/CR-4043 (ORNL/ TM-9943), September 1985.

7. M. F. Osborne. J. L. Collins, R. A. Lorenz. J. R. Travis, and C. S. Webster, "Design. Construction. and Testing of a $2000^{\circ} \mathrm{C}$ Furnace and Fission Product Collection System," NUREG/ CR-3715 (ORNL/TM-9135). September 1984.
8. J. L. Collins, M. F. Osborne, R. A. Lorenz, K. S. Norwood, J. R. Travis, and C. S. Webster, "Observed Behavior of Cesium, Iodine, and Tellurium in the ORNL Fission Product Release Program," NUREG/CR-3930 (ORNL/TM-9316), February 1985.

9. K. S. Norwood, "An Assessment of Thermal Gradient Tube Results from the HI Series of Fission Product Release Tests, " NUREG/CR-4105 (ORNL/TM-9506), March 1985.

10. M. F. Osborne, J. L. Collins, P. A. Haas, R. A. Lorenz, J. R. Travis, and C. S. Webster, "Design and Final Safety Analysis Report for Vertical Furnace Fission Product Release Apparatus in Hot Cell B, Building 4501," NUREG/CR-4332 (ORNL/TM-9720), March 1986.

11. M. F. Osbome, J. L. Collins, and R. A. Lorenz, "Highlights Report for Fission Product Release Tests of Simulated LWR Fuel," ORNL/NRC/LTR-85/1, February 1985.

12. Toshiyuki Yamashita, "Steam Oxidation of Zircaloy Cladding in the ORNL Fission Product Release Tests," NUREG/CR-4777 (ORNL/TM-10272), March 1988.

13. S. K. Wisbey, "Preliminary Studies of the Morphology of Thermal Gradient Tube Deposits for Fission Product Release Experiments," NUREG/CR-4778 (ORNL/TM-10273), March 1988.

14. C. S. Webster and M. F. Osborne, "The Use of Fiber Optics for Remote Temperature Measurement in Fission Product Release Tests," NUREG/CR-4721 (ORNL/TM-10366), April 1989.

15. M. F. Osborne, J. L. Collins, R. A. Lorenz, J. R. Travis, C. S. Webster, and T. Yamashita, "Data Summary Report for Fission Product Release Test VI-1," NUREG/CR-5339 (ORNL/ TM-11104), June 1989.

16. M. F. Osborne, J. L. Collins, R. A. Lorenz, J. R. Travis, and C. S. Webster, "Data Summary Report for Fission Product Release Test VI-2," NUREG/CR-5340 (ORNL/TM-11105), September 1989. 
17. M. F. Osborne. J. L. Collins, R. A. Lorenz. J. R. Travis, C. S. Webster, H. K. Lee, T. Nakamura, and Y.-C. Tong, "Data Summary Report for Fission Product Release Test VI-3," NUREG/CR-5480 (ORNL/TM-11399), April 1990.

18. M. F. Osborne, R. A. Lorenz, J. L. Collins, J. R. Travis, C. S. Webster, and T. Nakamura. "Data Summary Report for Fission Product Release Test VI-4," NUREG/CR-5481 (ORNL/TM-1 1400), October 1990.

19. M. F. Osborne, R. A. Lorenz, J. R. Travis, C. S. Webster, and J. L. Collins, "Data Summary Report for Fission Product Release Test VI-5," NUREG/CR-5666 (ORNL/TM-11743), October 1991.
20. M. F. Osborne, R. A. Lorenz, J. R. Travis, C. S. Webster, and J. L. Collins, "Data Summary Report for Fission Product Release Test VI-6," NUREG/CR-6077 (ORNL/TM-12416), March 1994.

21. M. F. Osborne, R. A. Lorenz, J. R. Travis, "Preliminary Results from ORNL Fission Product Release Test VI-7," ORNL/NRC/LTR-94/2, February 1994.

22. R. A. Lorenz and M. F. Osborne, "A Summary of ORNL Fission Product Release Tests with Recommended Release Rates and Diffusion Coefficients," NUREG/CR-6261 (ORNL/TM-12801) to be published. 


\section{Introduction}

This report summarizes data from the seventh hightemperature test in a vertical test apparatus. This series of tests was designed to investigate fission product release from light-water-reactor (LWR) fuel as functions of temperature (in the range of 2000 to $2700 \mathrm{~K}$ ) and atmosphere (steam, air, and/or hydrogen) at atmospheric pressure. Six tests in an earlier series, denoted HI-1 through HI-6, were conducted in a horizontal furnace under similar conditions-temperatures of 1675 to $2275 \mathrm{~K}\left(1400\right.$ to $\left.2000^{\circ} \mathrm{C}\right)$ in steam atmospheres. The $\mathrm{HI}$ series tests were analyzed and reported previously,' and comparable data summary reports are listed as items 1 through 6 in the Foreword. After revising the test apparatus to accommodate the vertical furnace, a new series of tests to higher temperatures, denoted VI-1 through VI-7, was initiated. ${ }^{2-7}$ All of this work has been summarized in Nuclear Safery. ${ }^{8}$

The purpose of this project. which is sponsored by the U.S. Nuclear Regulatory Commission (NRC), is to obtain the experimental data needed to reliably assess the consequences of a variety of hearup accidents in LWRs. The specific objectives were

1. to obtain fission product release and behavior data applicable to the analysis of reactor accidents and
2. to apply these data to the development of fission product release and transport models.

Tests of high-burnup LWR fuel were emphasized throughout this project. However, the applicability of simulated fuel (unirradiated $\mathrm{UO}_{2}$ containing radioactive fission product tracers) was considered, and several simulant tests were conducted to provide valuable data about the behavior of specific fission product species ${ }^{10}$ and to allow comparison of results with other experimental work." All tests have been conducted at atmospheric pressure in helium mixed with a reactive gas (steam, air, and/or hydrogen) in a hot cell-mounted test apparatus. ${ }^{12}$

The procedures and techniques used in preparing and conducting Test VI-7, as well as in posttest examination and analysis, were very similar to those used in earlier tests. The analytical techniques employed are listed in Table 1.1. This report provides a brief description of this test and a compilation of all available results. Thorough data evaluation and correlation of all results through Test VI- 6 are included in a recent comprehensive review. ${ }^{13}$. 
Introduction

Table 1.1. Analytical techniques used for fission product analysis

\begin{tabular}{|c|c|c|c|}
\hline Technique & Time & Location & Elements \\
\hline \multirow[t]{3}{*}{ Gamma spectrometry } & Pretest, posttest & Fuel specimen & $\begin{array}{l}\text { Long-lived, gamma-emitting } \\
\text { fission products - Ru, Sb, Cs, } \\
\mathrm{Ce}, \mathrm{Eu}\end{array}$ \\
\hline & On-line & $\begin{array}{l}\text { Thermal gradient tube } \\
\text { (TGT), charcoal traps, } \\
\text { filters }\end{array}$ & $\mathrm{Cs}, \mathrm{Kr}$ \\
\hline & Posttest & $\begin{array}{l}\text { Furnace components, TGT, } \\
\text { filters }\end{array}$ & $\mathrm{Ru}, \mathrm{Sb}, \mathrm{Cs}, \mathrm{Ce}, \mathrm{Eu}$ \\
\hline $\begin{array}{l}\text { Neutron activation } \\
\text { analysis }\end{array}$ & Posttest & $\begin{array}{l}\text { Charcoal; solutions from } \\
\text { furnace, TGT, filters }\end{array}$ & $\mathrm{I}, \mathrm{Br}$ \\
\hline Chemical analysis & Posttest & Furnace, filters & $\mathrm{U}, \mathrm{Pu}$ \\
\hline $\begin{array}{l}\text { Inductively coupled } \\
\text { plasma-emission } \\
\text { spectrometry }\end{array}$ & Posttest & $\begin{array}{l}\text { Acid solutions from } \\
\text { furnace, TGT, or filters }\end{array}$ & $\begin{array}{l}\text { Many cations, especially } \mathrm{Sr} \\
\text { Mo, } \mathrm{Ru}, \mathrm{Te}, \mathrm{Ba}, \mathrm{U}\end{array}$ \\
\hline
\end{tabular}


Description

\section{Test Description}

The vertical test apparatus 12 is operated remotely and is capable of conducting tests at temperatures up to $2700 \mathrm{~K}$ for time periods up to $60 \mathrm{~min}$ in reactive atmospheres, such as steam, air, and/or hydrogen mixed with helium. Details of the furnace are shown in Figure 2.1, and the entire test apparatus installed in the hot cell is illustrated in Figure 2.2. Both manual and automatic optical pyrometers are used for temperature measurement, supplemented by thermocouples during the lowtemperarure heatup phase. Temperature control is accomplished by manual operation of the radiofrequency power supply.

The released fission products are collected in three sequentially operated, parallel collection trains. Each train is composed of (1) a $7.6-\mathrm{mm}$-ID platinum or stainiess steel-lined thermal gradient tube (TGT) designed for vapor condensation, (2) a filter package containing graduated fiberglass rilters for aerosol collection and heared charcoal that had been impregnated with Triethylenediamine (TEDA) for iodine sorption. and (3) cold charcoal traps for rare gas collection. The online releases of ${ }^{85} \mathrm{Kr}$ and ${ }^{\mathrm{i} 37} \mathrm{Cs}$ are monitored by $\mathrm{NaI}(\mathrm{Tl})$ detectors observing these collector components (see Figure 2.2). In steam atmosphere tests, a hot $\mathrm{CuO}$ bed is used to oxidize the hydrogen generated by reaction of steam with the Zircaloy cladding. The collection of this water in a condenser is measured continuously by a modified conductivity meter, thereby indicating the oxidation rate of the cladding. Details of the fission product collection system are shown in Figure 2.3. Included in the Test VI-7 apparans were three radiation detectors that were collimated to monitor the radioactivity (especially ${ }^{134} \mathrm{Cs},{ }^{137} \mathrm{Cs}$. and ${ }^{154} \mathrm{Eu}$ ) in the top, middle, and bottom regions of the ruel specimen. Data from these instruments should indicate any movement or collapse of the riel during the test.

The tests conducted in this vertical apparans assumed that temperature ( 2000 to $2700 \mathrm{~K}$ ) was the dominant variable. The flow rates of reactive gas $(-1.0 \mathrm{~L} / \mathrm{min})$ and time at high temperature ( $\sim 60 \mathrm{~min})$ were considered to be important but secondary variables. The objectives of this particular test were to obtain release rate data from the Monticello boiling water reactor (BWR) fuel heated at 2000 and $2300 \mathrm{~K}$ in moist air to effect oxidation of the Zircaioy cladding, and perhaps of the $\mathrm{UO}_{2}$ fuel. Test VI-1 in which a specimen of Oconee fuel of the same burnup was heated under the same time and temperature conditions in steam (no air) provided a basis for comparing atmospheric effects.

\subsection{Fuel Specimen Data}

The fuel specimen used in this test was cut from fuel rod G5 of bundle BND-0304, which had been irradiated in the Monticello BWR from May 1974 to February 1980 , attaining a burmup of $40.3 \mathrm{MWd} / \mathrm{kg} U$ as part of an extended burnup program. The available fabrication and irradiation data are summarized in Table 2.1, and postirradiation examination of this fuel was described by Pasupathi et al. ${ }^{14}$ Fission product inventories for the specimen were measured by direct gamma spectrometry of the fuel (for the long-lived gamma-emitting species only) and were calculated with the ORIGEN2 computer program, ${ }^{15}$ as shown in Tables 2.2 and 2.3. Since a specimen from the same Monticello fuel rod was heated to about the same temperature in Test HI-6, comparison of Tests VI-7 and HI-6 results will be appropriate.

Fission gas release data and gamma scans for the entire rod before it was sectioned were reported by Pasupathi et al. ${ }^{14}$ These data indicated that the rod had experienced no unusual temperature. power, or burnup histories during irradiation. Therefore, we assumed that no unusual fission product migration and/or reactions had occurred. Based on the available information, we estimate that $-2 \%$ of the total krypton generated in the fuel specimen had been released during irradiation.

In preparation for use in Test VI-7, tapered end caps of Zircaloy-2 were pressed onto the ends of the $15-\mathrm{cm}$-long fuel specimen. These end caps were not expected to provide gas seals, but rather to prevent loss of the fractured $\mathrm{UO}_{2}$ fuel during subsequent handling. Because the original bottom end cap had not included the pin to facilitate vertical mounting, a second end cap with a mounting pin was pressed onto the original end cap prior to Test VI-7. A small hole, $1.6 \mathrm{~mm}$ in diameter, was drilled through the cladding at midlength to serve as a standard leak for gas release during the heatup phase of the test. These details are shown in Figure 2.4.

The axial distributions of several fission products in the fuel specimen. as determined by gamma-ray spectrometry through a $1-\mathrm{cm}$ window at $1-\mathrm{cm}$ intervals, is shown in 
Description

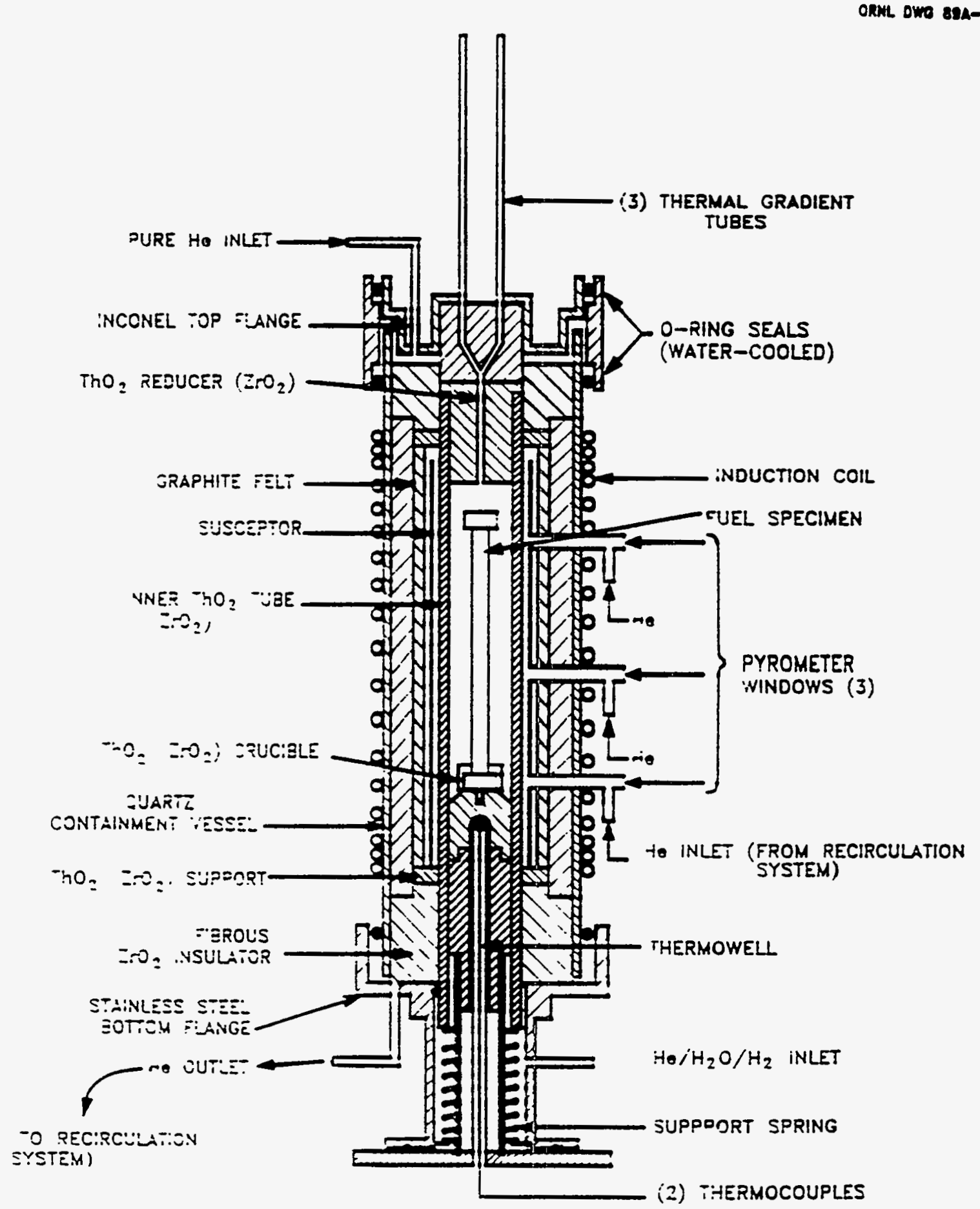

Figure 2.1 Vertical fission product release furnace. as used in Test VI-6 
Description

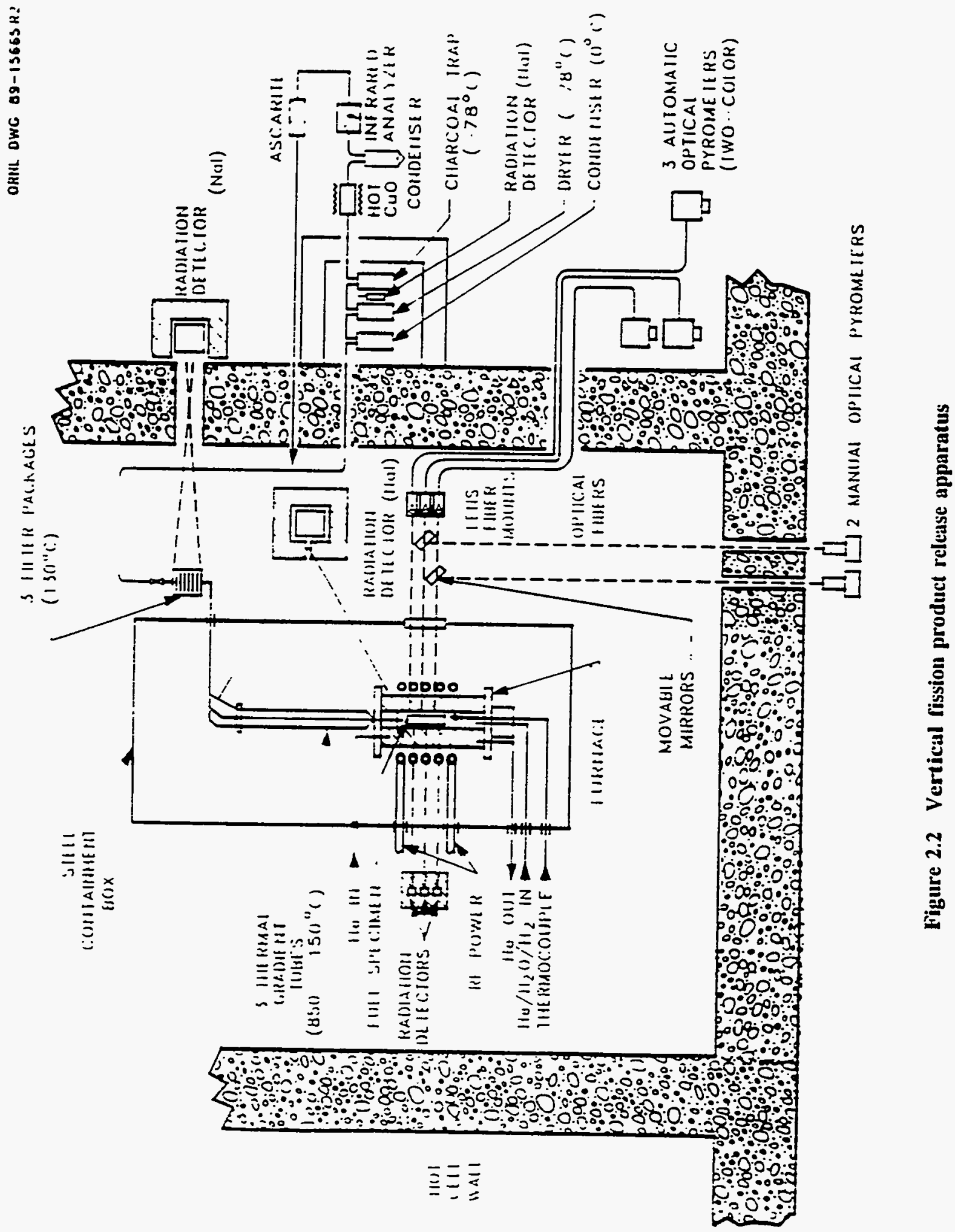




\section{Description}

ORNL DWG 90-14768

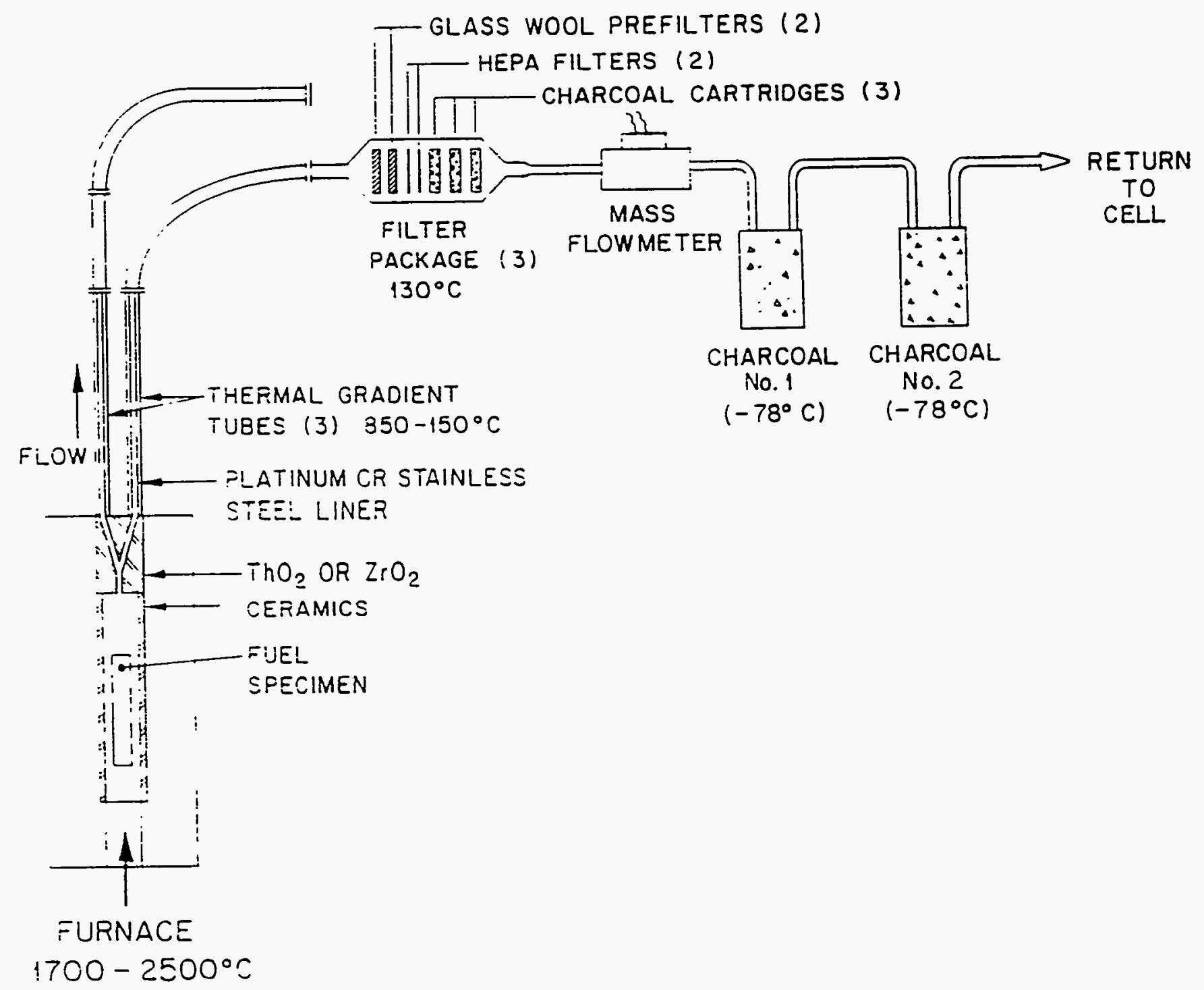

Figure 2.3 Components of the fission product collection system 
Table 2.1 Data for fuel specimen used in Test VI-7

Fuel rod identification

Bundle type

Irradiation data

Period

Average burnup of rod

Burnup of test specimen

Fuel rod characteristics (unirradiated)

Zircaloy-4 cladding

Initial enrichment

Initial helium fill

Test specimen characteristics

Length

Specimen fuel loading

Weight of Zircaloy cladding and end caps

Total weight of specimen

Gas release during irradiation
BND-0304 (G-5)

Section 3

$\mathrm{GE}, 8 \times 8$

May 1974 to February 1980

$-31.4 \mathrm{MWd} / \mathrm{kg}$

$\sim 40.3 \mathrm{MWd} / \mathrm{kg}$

1.243-cm (0.489-in.) OD

1.072-cm (0.422-in.) ID

$2.87 \%{ }^{235} \mathrm{U}$

Atmospheric pressure

$15.2 \mathrm{~cm}$ (6.0 in.)

$126.0 \mathrm{~g} \mathrm{UO}_{2}(112.3 \mathrm{~g} \mathrm{U})$

52.5

178.5

$1.6 \%$ (from whole rod)

$2 \%$ (from specimen) 


\section{Description}

Table 2.2 Test VI-7 fuel fission product inventories (calculated using ORIGEN2 on 8/14/84)

\begin{tabular}{lcc}
\hline Element & $\begin{array}{c}\text { Monticello fuel rod } \\
\text { (g/MTHHM, 7/15/81) }\end{array}$ & $\begin{array}{c}\text { VI-7 specimen } \\
\text { (g at 7/94) }\end{array}$ \\
\hline $\mathrm{Kr}$ & $4.126 \mathrm{E}+02$ & $4.63 \mathrm{E}-02$ \\
$\mathrm{Rb}$ & $3.874 \mathrm{E}+02$ & $4.35 \mathrm{E}-02$ \\
$\mathrm{Sr}$ & $9.450 \mathrm{E}+02$ & $1.06 \mathrm{E}-01$ \\
$\mathrm{Y}$ & $5.085 \mathrm{E}+02$ & $5.71 \mathrm{E}-02$ \\
$\mathrm{Zr}$ & $4.108 \mathrm{E}+03$ & $4.61 \mathrm{E}-01$ \\
$\mathrm{Mo}$ & $4.039 \mathrm{E}+03$ & $4.54 \mathrm{E}-01$ \\
$\mathrm{Ru}$ & $2.857 \mathrm{E}+03$ & $3.21 \mathrm{E}-01$ \\
$\mathrm{Sb}$ & $3.027 \mathrm{E}+01$ & $3.40 \mathrm{E}-03$ \\
$\mathrm{Te}$ & $5.985 \mathrm{E}+02$ & $6.72 \mathrm{E}-02$ \\
$\mathrm{I}$ & $2.389 \mathrm{E}+02$ & $2.68 \mathrm{E}-02$ \\
$\mathrm{Xe}$ & $6.354 \mathrm{E}+03$ & $7.14 \mathrm{E}-01$ \\
$\mathrm{Cs}$ & $3.302 \mathrm{E}+03$ & $3.71 \mathrm{E}-01$ \\
$\mathrm{Ba}$ & $1.868+03$ & $2.10 \mathrm{E}-01$ \\
$\mathrm{Ce}$ & $2.891 \mathrm{E}+03$ & $3.25 \mathrm{E}-01$ \\
$\mathrm{Eu}$ & $2.055 \mathrm{E}+02$ & $2.31 \mathrm{E}-02$ \\
$\mathrm{Total} \mathrm{FP}$ & & \\
$\mathrm{U}$ & $4.147 \mathrm{E}+04$ & $4.66 \mathrm{E}+00$ \\
$\mathrm{Pu}$ & $9.476 \mathrm{E}+05$ & $1.06 \mathrm{E}+02$ \\
\hline
\end{tabular}

Initial loading in Test VI-7 fuel specimen was $112.3 \mathrm{~g} \mathrm{U}$ or 1.123E-4 MTIHM.

-I values corrected: ORIGEN2 $\times 0.82$. 
Table 2.3 Test VI-7 fuel inventories and radioactivities (Monticello fuel, from ORIGEN2 calculation of 8/14/84)

\begin{tabular}{|c|c|c|c|c|}
\hline \multirow[b]{2}{*}{ Nuclide } & \multicolumn{2}{|c|}{$\begin{array}{c}\text { ORIGEN2 at } 7 / 15 / 81 \\
\text { Monticello fuel }\end{array}$} & \multicolumn{2}{|c|}{ Test VI-7 specimen" } \\
\hline & (Ci/MTIHM) & (g/MTTHM) & (Ci at 7/94) & (g at $7 / 94$ ) \\
\hline${ }^{60} \mathrm{Co}$ & $3.933 E+02$ & $3.477 \mathrm{E}-01$ & $7.995 \mathrm{E}-03$ & $3.905 \mathrm{E}-05$ \\
\hline${ }^{85} \mathrm{Kr}$ & $8.744 E+03$ & $2.228 \mathrm{E}+01$ & $4.238 \mathrm{E}-01$ & $2.502 \mathrm{E}-03$ \\
\hline${ }^{90} \mathrm{Sr}$ & $7.553 \mathrm{E}+04$ & $7.535 \mathrm{E}+\infty 0$ & $6.217 \mathrm{E}+00$ & $8.462 E-04$ \\
\hline${ }^{106} \mathrm{Ru}$ & $1.829 \mathrm{E}+05$ & $5.464 \mathrm{E}+01$ & $2.688 \mathrm{E}-03$ & $6.136 E-03$ \\
\hline${ }^{125} \mathrm{Sb}$ & $9.482 E+03$ & $9.108 \mathrm{E}+\infty 0$ & $4.122 E-02$ & $1.031 E-03$ \\
\hline${ }^{129} \mathrm{I}$ & $3.214 \mathrm{E}-02$ & $1.820 E+02$ & $3.609 E-06$ & $2.044 \mathrm{E}-02$ \\
\hline${ }^{134} \mathrm{Cs}$ & $1.158 \mathrm{E}+05$ & $8.950 E+01$ & $1.641 E-01$ & $1.005 E-02$ \\
\hline${ }^{137} \mathrm{Cs}$ & $1.189 E+05$ & $1.336 \mathrm{E}+03$ & $9.906 \mathrm{E}+00$ & $1.534 \mathrm{E}-01$ \\
\hline${ }^{144} \mathrm{Ce}$ & $1.875 E+05$ & $5.875 E+01$ & $1.958 \mathrm{E}-04$ & $6.598 \mathrm{E}-03$ \\
\hline${ }^{154} \mathrm{Eu}$ & $1.376 \mathrm{E}+04$ & $5.096 \mathrm{E}+01$ & $5.552 \mathrm{E}-01$ & $5.723 E-03$ \\
\hline Total FP & $1.367 \mathrm{E}+06$ & $4.147 \mathrm{E}+04$ & $1.732 E+01$ & $4.657 \mathrm{E}+00$ \\
\hline${ }^{235} \mathrm{U}$ & $8.486 E-03$ & $3.924 \mathrm{E}+03$ & $9.530 \mathrm{E}-07$ & $4.407 E-01$ \\
\hline${ }^{238} \mathrm{U}$ & $3.160 E-1) 1$ & $9.397 \mathrm{E}+05$ & $3.549 E-05$ & $1.055 \mathrm{E}+02$ \\
\hline Total U & $5.003 \mathrm{E} \div 00$ & $9.476 \mathrm{E}+05$ & $3.644 \mathrm{E}-05$ & $1.064 \mathrm{E}+02$ \\
\hline${ }^{29} \mathrm{Pu}$ & $4.559 \mathrm{E}+03$ & $2.662 E+02$ & $4.620 E-01$ & $2.989 E-02$ \\
\hline${ }^{29} \mathrm{Pu}$ & $3.083 E \div 02$ & $4.958 \mathrm{E}+03$ & $3.461 E-02$ & $5.568 E-01$ \\
\hline${ }^{ \pm 0} \mathrm{Pu}$ & $5.878 \mathrm{E} \div 02$ & $2.578 \mathrm{E}+03$ & $6.592 E-02$ & $2.895 E-01$ \\
\hline$\therefore+\mathrm{Pu}$ & $1.455 \mathrm{E} \div 05$ & $1.412 \mathrm{E}+03^{\circ}$ & $8.854 E+00$ & $1.586 \mathrm{E}-01$ \\
\hline$=22 \mathrm{Pu}$ & $3.018 E \div 00$ & $7.903 \mathrm{E}+02$ & $3.389 \mathrm{E}-04$ & $8.874 E-02$ \\
\hline Total Pu & $1.509 \mathrm{E}+05$ & $1.000 \mathrm{E}+04$ & $9.417 \mathrm{E}+00$ & $1.123 \mathrm{E}+00$ \\
\hline
\end{tabular}

"Initial loading in Test VI-7 fuei sp̣ecimen was $112.3 \mathrm{~g} \mathrm{U}$. or $1.123 \mathrm{E}-4$ MTIHM. 


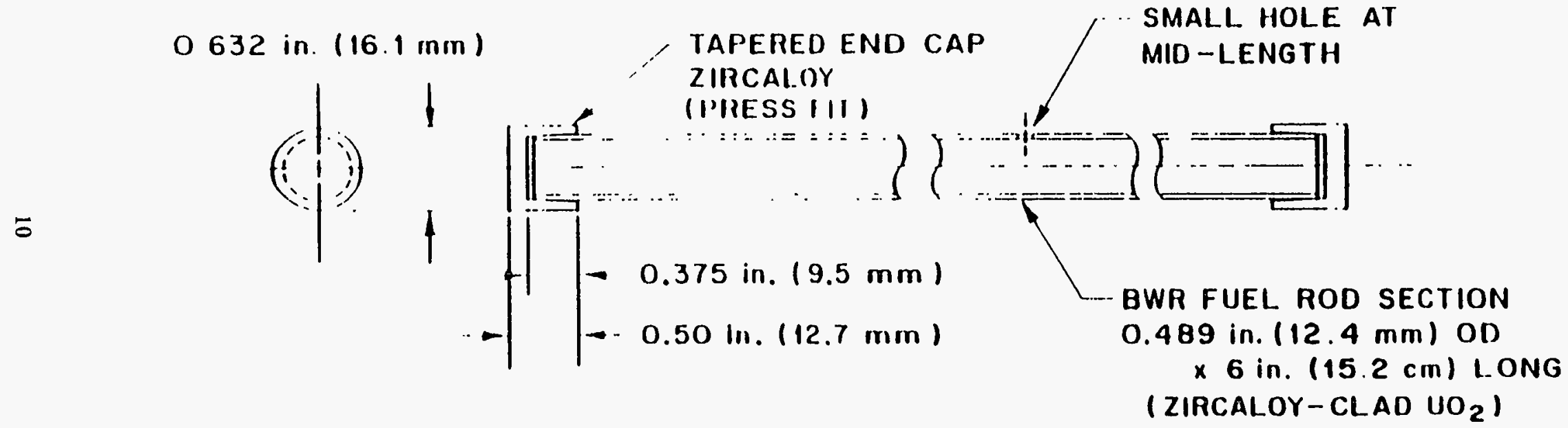

I'igure 2.4 Dimensions of fucl specimen used in Test VI-7 
Figure 2.5. This profile indicates uniform burnup of the fuel and fission product content along the specimen.

\subsection{Test Conditions and Operation}

As in each of the previous experiments, the test apparatus was assembled by direct handling, which is possible because the hot cell and test apparans are decontaminated after each test. Also, new $\mathrm{ZrO}_{2}$ furnace components, new TGT liners of 0.003-in. $(0.076-\mathrm{mm})$-thick platinum, and new filter package components were prepared and installed. In most previous tests, platinum TGT liners have been used to provide a relatively unreactive surface for the deposition of fission products, so that effects on the chemical forms of the deposits would be minimized. In some cases, however, stainless steel liners have been used to simulate the effects of realistic reactor material on the deposits. Only the transfer and loading of the highly radioactive fuel specimen and the final closure of the furnace and containment box were done remotely, and no in-cell operations were required during the test. Before heating was begun. the test apparatus was evacuated and purged with helium.

This test was intended to investigate the effects of oxidation by moist air on fission product release at $2300 \mathrm{~K}$. In earlier tests in steam. the oxidized cladding had remained largely intact, serving as a barrier to eifective $\mathrm{UO}_{2}$-steam contact, but no air had been included in previous high temperature tests. The operating conditions are summarized in Table 2.4, and the temperature history is shown in Figure 2.6. The heatup rate in Test VI-7 was $-25 \mathrm{~K} / \mathrm{min}$. and the cooldown rate (after the high temperanure period) was $-33 \mathrm{~K} / \mathrm{min}$.

The more important events during the test are listed in the test chronology (Table 2.5). The time periods for operation of the three collection trains (see Figure 2.6) were 0 to $85 \mathrm{~min}$ for Train A: 85 to 95 min for Train B; and $95 \mathrm{~min}$ to the end of the test. $-211 \mathrm{~min}$, including cooldown for Train C. A preheat period was included to slowly heat the specimen to $-550 \mathrm{~K}$ in helium prior to beginning airflow to the furnace. Time zero was defined as that time when the controlled heating ramp was begun, with stable gas (moist air + helium) flow through the warm furnace established. Temperature measurement and control were generally good. The 6 -min period at $\sim 1425 \mathrm{~K}$ was included to compare the data from the optical pyrometers, thereby ensuring accurate temperature measurement and control, and to allow additional time for heatup of ceramics in the outlet end of the furnace before any significant release of fission cooldown for Train $C$. A preheat period was included to slowly heat the specimen to $-550 \mathrm{~K}$ in helium prior to beginning airflow to the furnace. Time zero was defined as that time when the controlled heating ramp was begun, with stable gas (moist air + helium) flow through the warm furnace established. Temperature measurement products had occurred. As indicated in Figure 2.6, the planned time/temperature conditions were accomplished.

The planned atmosphere for Test VI-7 was a mixture of $1-\mathrm{L} / \mathrm{min}$ air and $0.5-\mathrm{L} / \mathrm{min}$ helium sarurated with water vapor at $323 \mathrm{~K}\left(50^{\circ} \mathrm{C}\right)$. The initial water saturation temperature during test Phase $\mathrm{A}$ was set at $303 \mathrm{~K}\left(30^{\circ} \mathrm{C}\right)$, to limit the cladding oxidation rate and keep the $\mathrm{H} 2 / \mathrm{O} 2$ ratio below the ignition limit. Then, when a large fraction of the Zircaloy cladding had been oxidized at a fuel temperature of $2000 \mathrm{~K}$, the water saturation temperanure was quickly increased to $323 \mathrm{~K}\left(50^{\circ} \mathrm{C}\right)$ for the remainder of the test, as indicated in Table 2.4. The gas flow history for the entire test period is illustrated in Figure 2.7.

As in previous tests, a small amount of krypton release was observed early in the heating cycle (at -600 to $700 \mathrm{~K}$ ). This krypton is believed to be gas released from the fuel during irradiation and adsorbed on tuel and cladding surfaces until its desorption during the test heamp. As indicated in Figure 2.8. significant krypton release as a result of diffusion from the $\mathrm{UO}_{2}$ began at $-1630 \mathrm{~K}$ $\left(1357^{\circ} \mathrm{C}\right)$. A trace of cesium was detected on the TGT at a slightly lower temperature, $-1500 \mathrm{~K}$ $\left(1227^{\circ} \mathrm{C}\right)$. While the release of krypton appeared to cease at the end of the $2300 \mathrm{~K}$ (Phase C) test period. cesium collection on both TGT $C$ and filter $C$ continued for $-10 \mathrm{~min}$ as the fuel cooled. 


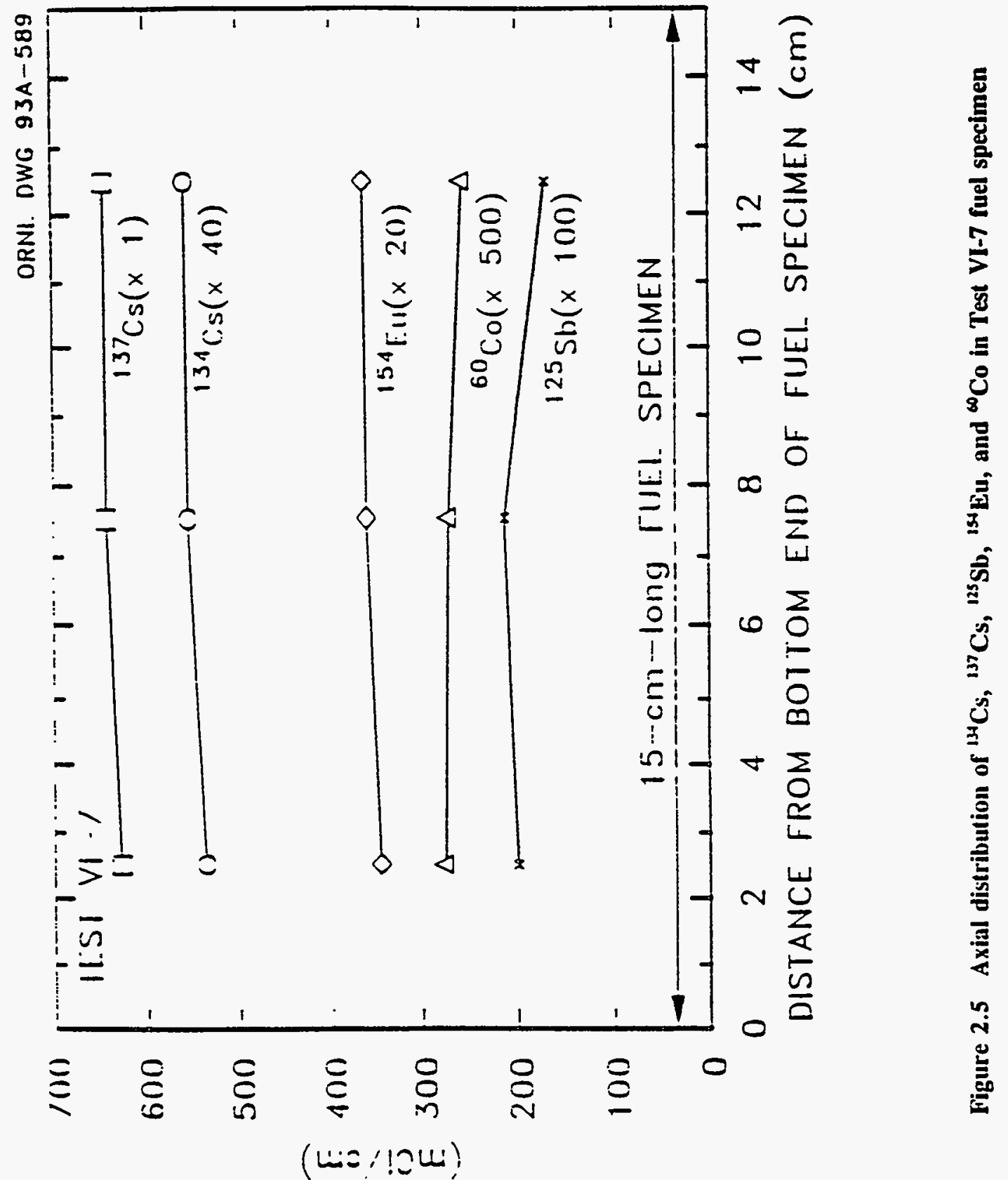

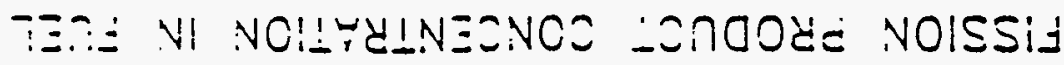


Table 2.4 Operating data for Test VI-7

\section{Specimen temperature}

At start of hearup ramp, $K$

During first plateau to check pyrometers, $\mathrm{K}$

Phase A heatup rate to $2000 \mathrm{~K}, \mathrm{~K} / \mathrm{min}$

During 20-min Phase A plateau, average, $\mathrm{K}$

Phase $B$ heatup rate to $2300 \mathrm{~K}, \mathrm{~K} / \mathrm{min}$

During 20-min Phase $C$ plateau. average, $K$

Cooldown rate, $\mathrm{K} / \mathrm{min}$

Time above $2000 \mathrm{~K}, \min$

Nominal gas flow rate $\left(\mathrm{L} / \mathrm{min} \text { at } 20^{\circ} \mathrm{C} \text { and } 1 \mathrm{bar}\right)^{a}$

During Phase A heatup to $2000 \mathrm{~K}$ :

Air to fuel specimen, sanurared with water at $30^{\circ} \mathrm{C}$

1.8

Helium to susceptor (and fuel specimen)

0.4

Helium to thermowell (and fuel specimen)

0.1

Recirculation/purification system

During 2000 and $2300 \mathrm{~K}$ test period:

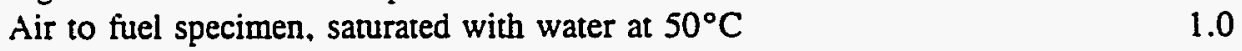

Helium to susceptor (and fuel specimen)

0.4

Helium to thermowell (and fuel specimen)

0.1

Recirculation/purification system

1.5

'Measured by mass flowmeters. Absolute pressure in furnace was $0.09925 \mathrm{MPa}(744.4$ $\mathrm{mm} \mathrm{Hg}$. 


\section{Description}

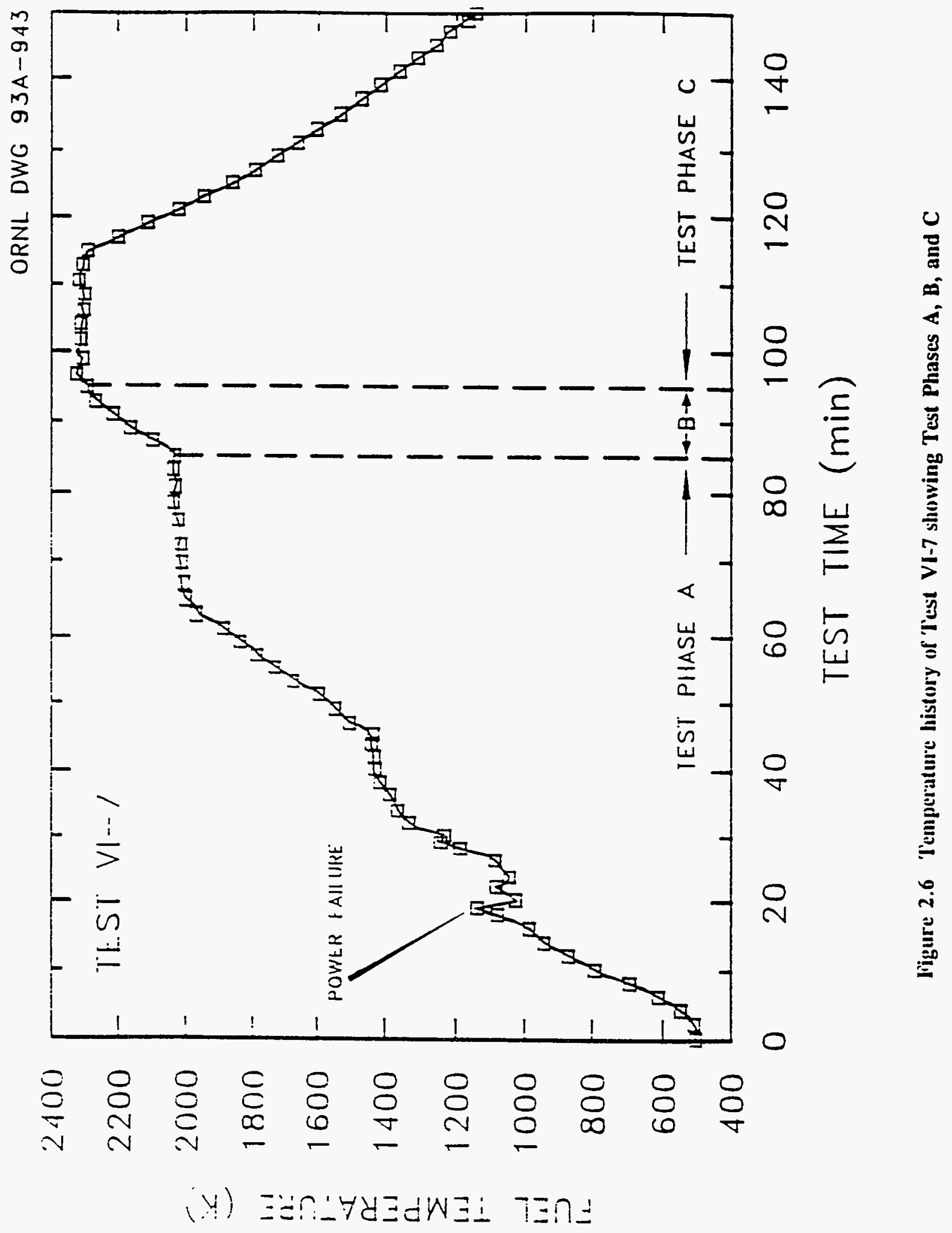


Description

Table 2.5 Chronology of Test VI-7, conducted September 16, 1993.

Fuel specimen loaded into furnace September 15, 1993

\begin{tabular}{|c|c|c|c|}
\hline Event/observation & $\begin{array}{l}\text { Clock } \\
\text { (h) }\end{array}$ & $\begin{array}{l}\text { Time } \\
\text { (min) }\end{array}$ & $\begin{array}{l}\text { Temperature at test } \\
\text { midpoint of fuel } \\
\text { (K, corrected) }\end{array}$ \\
\hline Vacuum and pressure tests & 930 & & \\
\hline Complete alarm checks & 1000 & & \\
\hline Begin system preheat & 1120 & & $\mathrm{RT}^{\bullet}$ \\
\hline Begin furnace preheat, with gas flow & & & \\
\hline to furnace & 1130 & & $\mathrm{RT}^{\bullet}$ \\
\hline Stable flow and temperanure & 1230 & & $480^{\cdots}$ \\
\hline \multicolumn{4}{|l|}{ Test Phase A } \\
\hline $\begin{array}{l}\text { Start ramp to }-1600 \mathrm{~K} \text {, } \\
\text { at } \sim 30 \mathrm{~K} / \mathrm{min}\end{array}$ & 1300 & 0 & $470 *$ \\
\hline Hearup based on thermocouple & 1320 & 20 & $960{ }^{\circ}$ \\
\hline Begin accurate pyrometer measurement & 1335 & 35 & 1305 \\
\hline Reached stable plateau & 1339 & 39 & 1424 \\
\hline Resume ramp to $2000 \mathrm{~K}$ & 1345 & 45 & 1434 \\
\hline Krypton release observed & 1352 & 52 & 1634 \\
\hline Cesium detected on TGT & 1358 & 58 & 1804 \\
\hline $\begin{array}{l}\text { Reached } 2000 \mathrm{~K} \text { plateau. } \\
\text { increase steam generator to } 50^{\circ} \mathrm{C}\end{array}$ & 1405 & 65 & 2000 \\
\hline After $20 \mathrm{~min}$ at $2000 \mathrm{~K}$, end Phase A & 1425 & 85 & 2033 \\
\hline \multicolumn{4}{|l|}{ Test Phase B } \\
\hline $\begin{array}{l}\text { Begin Phase } \mathrm{B} \text {. heat to } 2300 \mathrm{~K} \\
\text { at } \sim 30 \mathrm{~K} \text { 'min }\end{array}$ & 1425 & 85 & 2033 \\
\hline End Phase B. at $2300 \mathrm{~K}$ & 1435 & 95 & 2292 \\
\hline \multicolumn{4}{|l|}{ Test Phase C } \\
\hline Begin Phase C. $20 \mathrm{~min}$ at $2300 \mathrm{~K}$ & 1435 & 95 & 2292 \\
\hline Rapid cesium deposition on filters & 1437 & 97 & 2322 \\
\hline $\begin{array}{l}\text { End } 2300 \mathrm{~K} \text { plateau. reduce power } \\
\text { to cool at } \sim 50 \mathrm{~K} / \mathrm{min}\end{array}$ & 1455 & 115 & 2292 \\
\hline Power off & 1509 & 129 & 1724 \\
\hline Cooling at $-30 \mathrm{~K} / \mathrm{min}$ & 1520 & 140 & 1385 \\
\hline Air flow ended. helium continued & 1527 & 147 & 1214 \\
\hline Last pyrometer measurements & 1530 & 150 & 1146 \\
\hline End Phase C. helium flow reduced & 1631 & 211 & -500 \\
\hline
\end{tabular}

$\cdot \mathrm{RT}=$ room temperature.

-Based on thermocouple measurement. 


\section{Description}

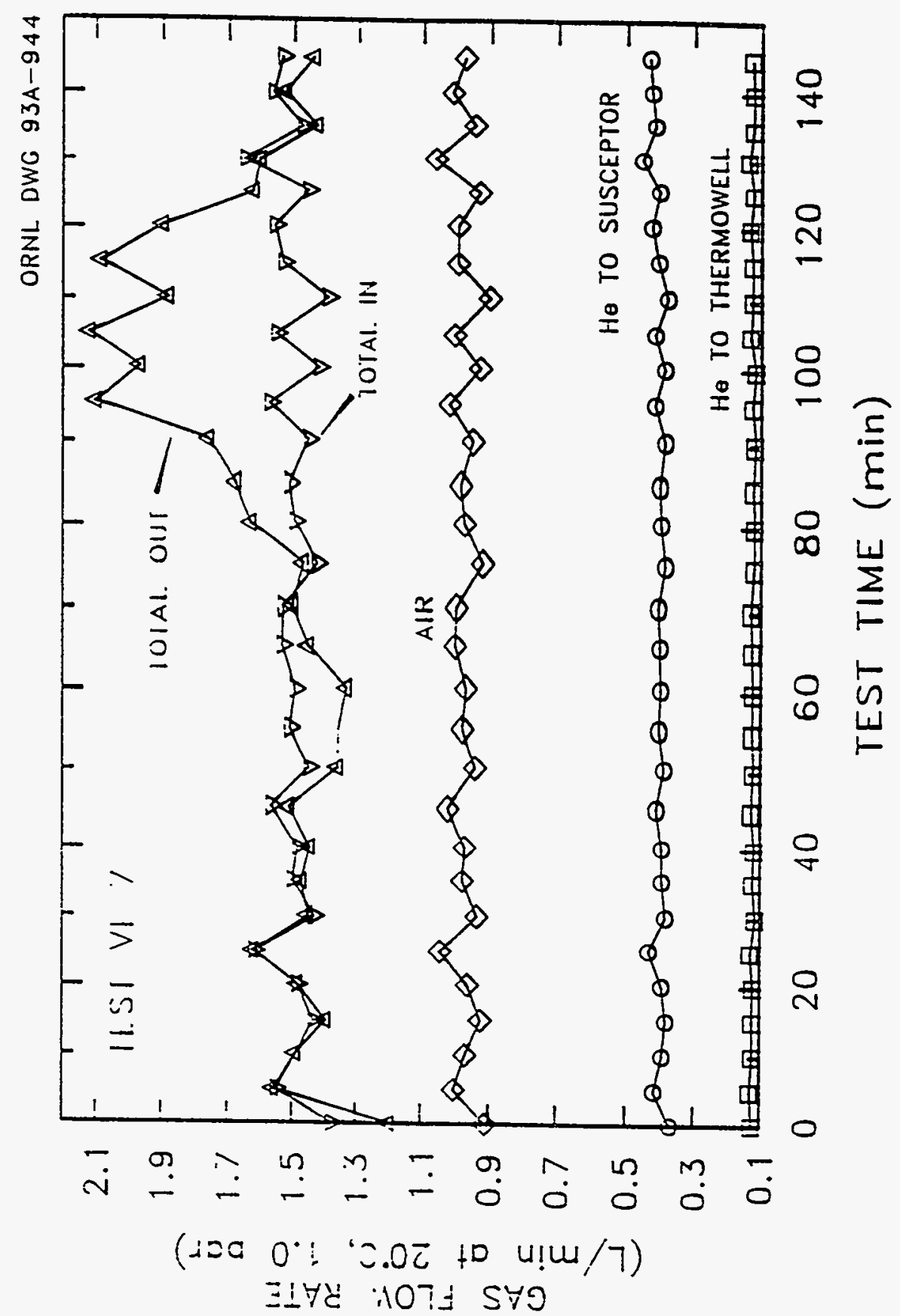

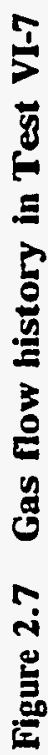




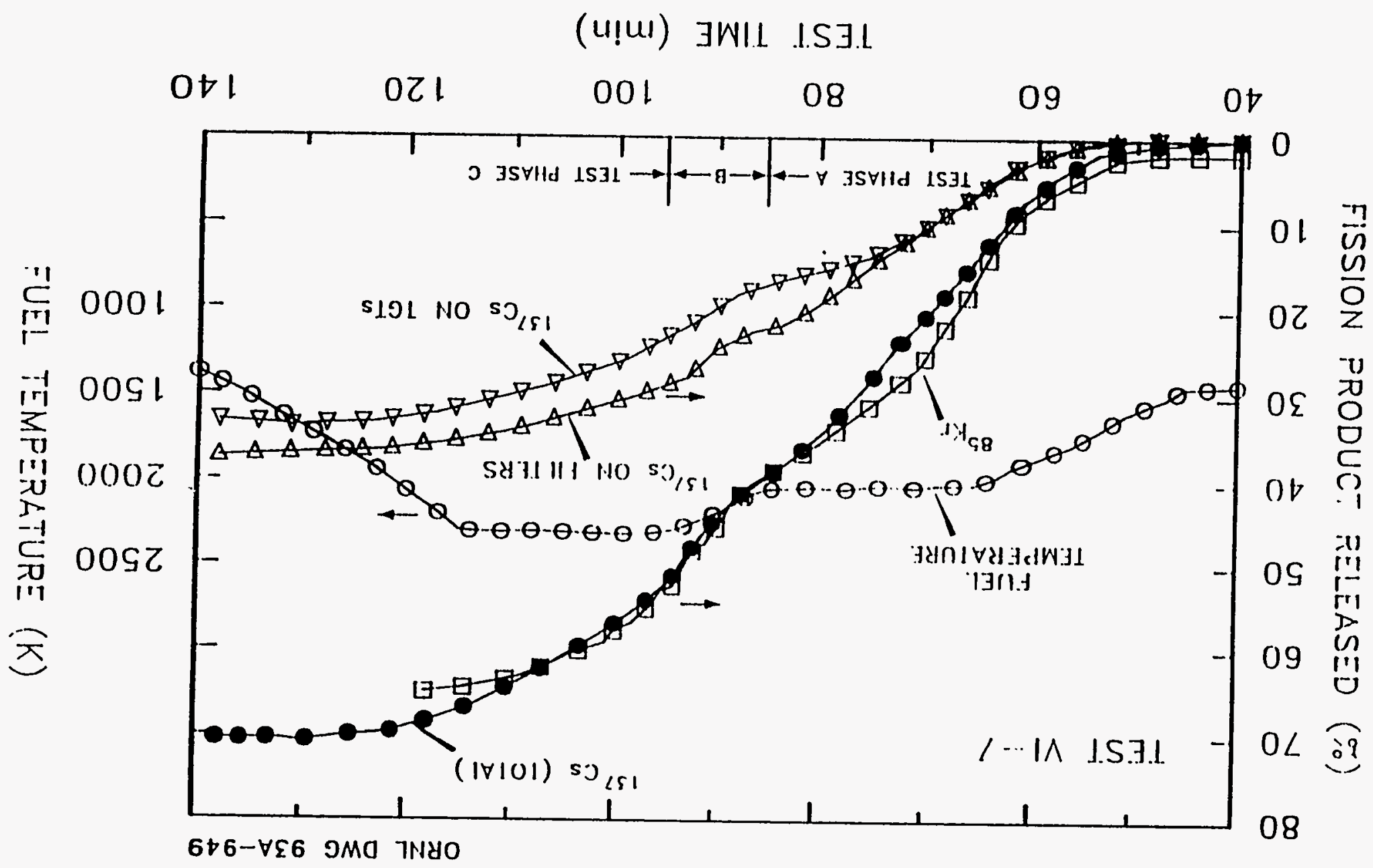




\section{Description}

\subsection{Posttest Disassembly and Examination}

Before disassembly was begun, the apparatus was monitored with an in-cell ion chamber for the distribution of radioactivity. The highest concentrations of radioactivity were found at the furnace exit (190 $\mathrm{rem} / \mathrm{h}$ ) and at about midlength of the TGTs (200 $\mathrm{rem} / \mathrm{h})$. Higher levels of radioactivity along the TGTs than on the filters $(-60 \mathrm{rem} / \mathrm{h})$ and the furnace $(-150$ $\mathrm{rem} / \mathrm{h}$ ) were at least partially a result of additional shielding and the distance from the source for the filters and furnace. These distributions and levels of radioactivity were similar to those found after previous VI tests at $2300 \mathrm{~K}$.

Initially, the filter assemblies and the furnace top flange-TGT assembly, containing the TGT liners, were removed,sealed, and transferred to another hot cell to avoid potential cross contamination from other components. The $\mathrm{ZrO}_{2}$ top end plug was removed from the furnace rube to allow observation of the interior, showing that the fuel specimen appeared to be in its initial upright position. After inspection, the furnace cavity was filled with epoxy resin to preserve the geometry of the degraded fuel specimen during handling, gamma spectrometry, sectioning, or any other operations. After removal of the fuel-furnace tube assembly from the furnace, it was analyzed in detail by gamma spectrometry then cut into short sections for visual examination. Two of these radial sections - one from near the bottom (inlet) end of the specimen and one from near the top (outlet) end were selected for metallographic examination to investigate the extent of cladding oxidation and changes in fuel microstructure. 
Results

\section{Test Results}

\subsection{Gamma Spectrometry Data}

After the test, all experimental components and collectors were analyzed under well-defined geometry for quantitative analysis of the gamma-emitting fission products. In order to determine the effective shielding to obtain a mass balance for cesium, the previously proven empirical method for adjusting the self-shielding factor for several of the principal ${ }^{134} \mathrm{Cs}$ gamma-ray energies was used.2 This technique provides good results for all of the long-lived, gamma-emitting nuclides.

Pretest gamma spectrometric analysis of the $15.2-\mathrm{cm}$-long fuel specimen was used to determine the fission product inventories of ${ }^{106} \mathrm{Ru},{ }^{125} \mathrm{Sb},{ }^{134} \mathrm{Cs},{ }^{137} \mathrm{Cs}$, and ${ }^{154} \mathrm{Eu}$ in the fuel and ${ }^{60} \mathrm{Co}$ in the cladding. As noted previously in Section 2, a calculation by the computer program ORIGEN2 supplied the inventory values for all fission products, activation products, and fuel nuclides; these are shown in Tables 2.2 and 2.3. Based on posttest measurements at $1-\mathrm{cm}$ intervals along the fuel specimen, as shown in Figure 3.1. the axial concentrations of cesium and antimony were lowest at the bottom (gas inlet) end, and increased with distance toward the top (gas outlet) end, indicating higher releases at the bottom end. Such a release gradient, which had not been observed in any previous test, could be the resuit of either a temperaure gradient (higher release at higher temperature) or an oxidation gradient (higher release with fuel oxidation) along the specimen. Neither experience nor operational data revealed any evidence of a temperature gradient. but calculations indicated that an oxidation gradient was likely. Whereas the lower end of the specimen was always exposed to excess oxygen and steam, rapid reactions with the Zircaloy cladding reduced the concentrations of these oxidants and produced hydrogen in place oi steam so that the atmospinere over the upper end of the specimen was reducing for almost half of the test period. Furthermore, radial sections of fuel that were selected for metallographic examination showed some differences in the appearance of the oxidized cladding. The results of these examinations will be discussed in Section 3.7. In addition to the tission products, the axial distribution of the ${ }^{60} \mathrm{Co}$ in the Zircaloy cladding, also shown in Figure 3.1, indicates higher release at the bottom end.
In general, we believe that ${ }^{144} \mathrm{Ce}$ is the best indicator of fuel location in gamma scans. Because of the long decay time for the fuel in Test VI-7 $(\sim 13 y)$, however, the counting precision for ${ }^{144} \mathrm{Ce}\left(\mathrm{T}_{12}=284 \mathrm{~d}\right)$ was poor. Therefore, ${ }^{154} \mathrm{Eu}$, which experienced high release under the reducing conditions in Tests VI -4 and VI-5 but only very low release $(<1 \%)$ in oxidizing environments, is considered to be the best indicator for the location of $\mathrm{UO}_{2}$ fuel in Test VI-7. As seen in Figure 3.1, the axial distribution of ${ }^{154} \mathrm{Eu}$ remained flat, indicating no significant redistribution of $\mathrm{UO}_{2}$ during the test.

As has been typical of these tests of high-burnup, longdecayed fuel, ${ }^{137} \mathrm{Cs}$ and ${ }^{134} \mathrm{Cs}$ were the dominant activities in almost all samples of released material and interfered with the analysis of less abundant fission products. The integral releases of krypton and cesium, as functions of time and temperature, are illustrated in Figure 2.8. These curves show high release rates for both krypton and cesium from the time temperatures reached $\sim 1800 \mathrm{~K}$ until cooldown began after completion of the $2300 \mathrm{~K}$ period, a total of $-60 \mathrm{~min}$. As observed in all previous tests, the release behaviors of krypton and cesium were quite similar throughout the test.

A summary of the fractional release results for ${ }^{85} \mathrm{Kr}$, ${ }^{125} \mathrm{Sb},{ }^{137} \mathrm{Cs}$, and ${ }^{60} \mathrm{Co}$, as determined by gamma spectrometry, is presented in Table 3.1. In addition, data for ${ }^{129} \mathrm{I}$, obtained by neutron activation analysis, are shown. Although no data for ${ }^{134} \mathrm{Cs}$ are shown, the agreement with ${ }^{137} \mathrm{Cs}$ was consistently good (within $\pm 3 \%$ ) at all locations. Since there is no apparent reason for a separation of the two cesium radionuclides, this is a good indication of the precision of the analyses.

The distribution of cesium within the test apparatus is shown in detail in Table 3.2. The fraction of the cesium released from the fuel but retained in the furnace, $-7 \%$, was typical of tests in oxidizing atmospheres. ${ }^{7}$ Previous studies of cesium deposited on $\mathrm{ZrO}_{2}$ furnace ceramics at high temperature $(>1300 \mathrm{~K})$ indicated a reaction to form a cesium compound, probably $\mathrm{Cs}_{2} \mathrm{ZrO}_{3} .{ }^{17}$ This compound appeared to be stable in the range -1100 to $1500 \mathrm{~K}$ but decomposed at higher temperatures. ${ }^{18}$ 
ORIIL OWG 93A-945

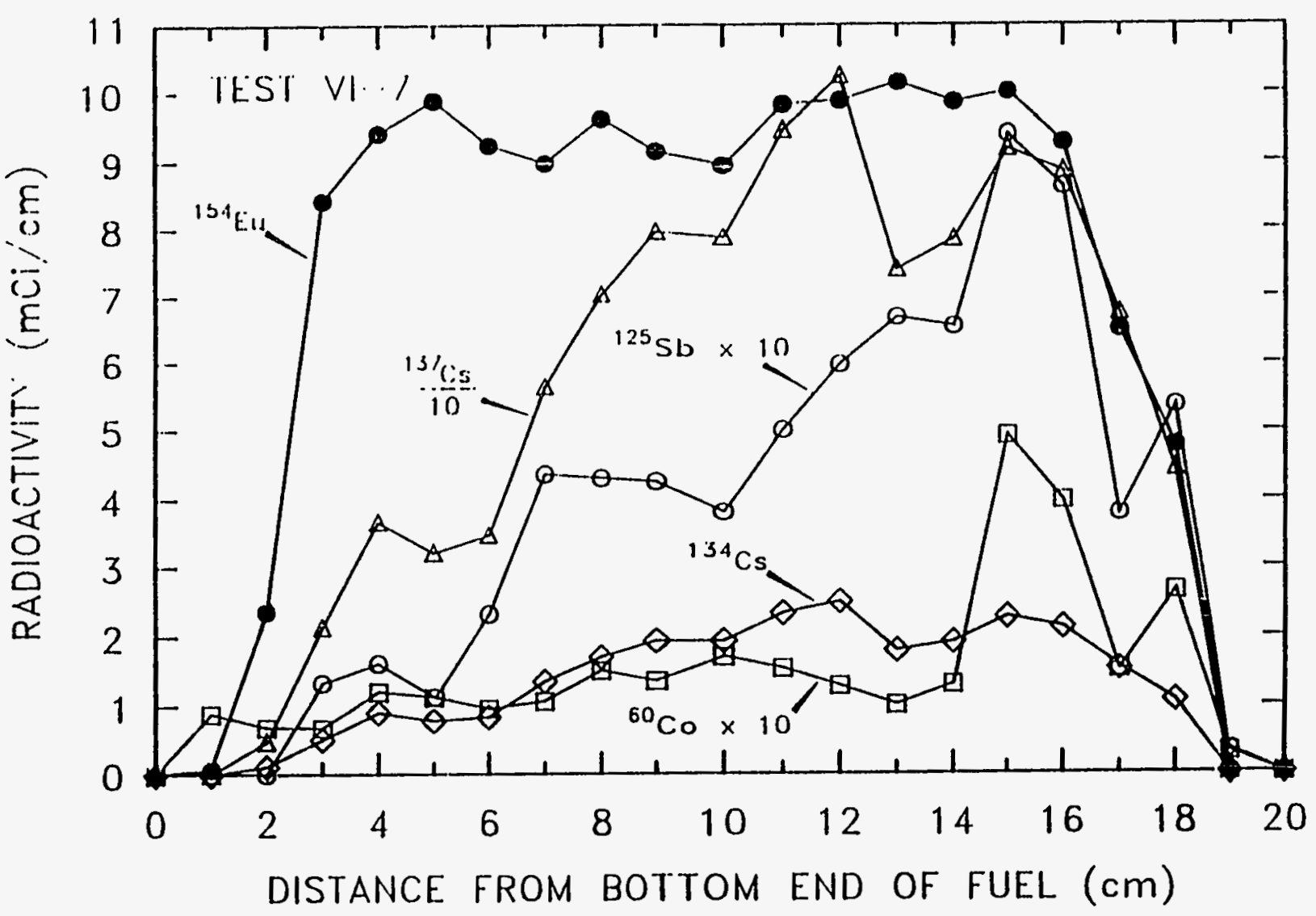

Figure 3.1 Distribution of radionuclides in fucl specimen after Test VI-7. Note lower concentrations of ${ }^{137} \mathrm{Cs}$ and ${ }^{125} \mathrm{Sb}$ near bottom (gas inlet) end of fuel 
Table 3.1 Summary of fission product release data for Test VI-7

\begin{tabular}{|c|c|c|c|c|c|c|}
\hline \multirow{2}{*}{$\begin{array}{l}\text { Component/ } \\
\text { collector }\end{array}$} & \multirow{2}{*}{$\begin{array}{c}\text { Operating time } \\
\text { at } \mathrm{T}>000 \mathrm{~K} \\
(\mathrm{~min})\end{array}$} & \multicolumn{5}{|c|}{ Percentage of fission product inventory collected during each test phase } \\
\hline & & ${ }^{85} \mathbf{K r}$ & ${ }^{129} \mathbf{I}$ & ${ }^{125} \mathrm{Sb}$ & ${ }^{137} \mathrm{Cs}$ & ${ }^{60} \mathrm{Co}{ }^{* *}$ \\
\hline Furnace & 57 & 0 & 1.7 & 25.3 & 7.3 & 22.0 \\
\hline $\begin{array}{l}\text { Train A } \\
\text { TGT } \\
\text { Filters } \\
\text { Total }\end{array}$ & 20 & 41 & 21.9 & $\begin{array}{l}0 \\
0 \\
0\end{array}$ & $\begin{array}{l}15.7 \\
21.0 \\
36.7\end{array}$ & $\begin{array}{l}0.32 \\
0.65 \\
0.97\end{array}$ \\
\hline $\begin{array}{c}\text { Train B } \\
\text { TGT } \\
\text { Filters } \\
\text { Total }\end{array}$ & 10 & 15 & 7.5 & $\begin{array}{l}0 \\
4.8 \\
4.8\end{array}$ & $\begin{array}{r}4.2 \\
6.4 \\
10.6\end{array}$ & $\begin{array}{l}0.50 \\
0.93 \\
1.43\end{array}$ \\
\hline $\begin{array}{l}\text { Train C } \\
\text { TGT } \\
\text { Filters } \\
\text { Total }\end{array}$ & & 13 & 10.3 & $\begin{array}{r}6.3 \\
15.2 \\
21.5\end{array}$ & $\begin{array}{r}8.0 \\
8.8 \\
16.8\end{array}$ & $\begin{array}{l}1.89 \\
3.53 \\
5.41\end{array}$ \\
\hline Total for test & 57 & 69 & 41.5 & 51.5 & 71.4 & 29.8 \\
\hline
\end{tabular}

'Inventories based on fuel analysis and ORIGEN2 calculations.

${ }^{-\infty} \mathrm{Co}$ is not a fission product, rather an activation product in the cladding. 
Table 3.3 Physical forms of cesium released from furnace in Test VI-7

\begin{tabular}{cccc}
\hline \multirow{2}{*}{ Collection period } & \multicolumn{3}{c}{ Amount in designated form (\% or inventory) } \\
\cline { 2 - 4 } & Vapor & Aerosol & Total \\
\hline A & 24.5 & 32.7 & 57.2 \\
B & 6.6 & 10.0 & 16.6 \\
C & 12.5 & 13.8 & 26.3 \\
Total $A+B+C$ & 43.6 & 56.5 & 100 \\
\hline
\end{tabular}


The cesium released from the furnace was approximately equally divided between vapor $(44 \%$, as indicated by condensation in the thermal gradient tubes) and aerosol $(56 \%$, as indicated by collection further downstream, primarily on the filters). These distribution data are shown in Table 3.3. The somewhat higher fraction in aerosol form is consistent with previous data under oxidizing conditions, whereas vapor forms have dominated under reducing (hydrogen atmosphere) conditions. ${ }^{6}$

The measured distributions for the released ${ }^{125} \mathrm{Sb}$ and ${ }^{6} \mathrm{Co}$ within the test apparatus are shown in Table 3.4. Although ${ }^{125} \mathrm{Sb}$ is of relatively low yield and is not among the most hazardous fission products, it has an intermediate-length half-life and strong gamma rays, which make it easily detected. Furthermore, ${ }^{: 5} \mathrm{Sb}$ has been shown to behave much like and to be a good indicator for tellurium, a highly hazardous fission product element that is more difficult to measure because it has no long-lived gamma-emitting isotopes. Like tellurium, we believe antimony is released from the fuel in elemental form but combines (probably as an alloy) with the Zircaloy cladding and is eventually released as the cladding approaches complete oxidation. 9 In addition, similar behavior for tellurium and antimony is indicated in the TGTs, as discussed by Norwood. ${ }^{20}$ The much larger amounts of ${ }^{137} \mathrm{Cs}$ compared with ${ }^{125} \mathrm{Sb}$ at all locations, because the cesium exceeded the antimony inventory in the fuel by more than two orders of magniude. indicate the difficuity in measuring small concentrations of ${ }^{135} \mathrm{Sb}$ accurately.

Because very little europium. which is relativeiy involatile under oxidizing conditions, has been released in previous tests in steam. very low release was expected in this test in air and steam. A small amount of ${ }^{154} \mathrm{Eu}(-0.04 \%$ of the fuel inventory) was measured on furnace components, but only trace amounts $(-0.001 \%)$ were detected on the filters. As shown in Table 3.4. 49\% of the released is $\mathrm{Sb}$ was found deposited on ceramic suriaces in the outlet region of the furnace, where temperatures were 1200 to $2000 \mathrm{~K}$ during the test. While ${ }^{60} \mathrm{Co}$ is not a fission product. but rather an activation product resulting from cobalt impurity in the Zircaloy cladding, it was measured to provide information about the behavior of strucrural materials. The distribution data shown in Table 3.4 indicate that some $74 \%$ of the cobalt released from the fuel specimen deposited in the turnace, and that $\sim 2 / 3$ of the cobalt released from the furnace was in aerosol form. As would be expected, $70 \%$ of the release occurred during Test Phase C, the 20-min period at $-2300 \mathrm{~K}$.

\subsection{Analysis for Iodine}

Since iodine has no long-lived, gamma-emitting nuclides, analytical methods other than gamma spectrometry must be used. Neutron activation of ${ }^{129} I$ to ${ }^{130} \mathrm{I}$, which can be counted easily, is a proven, sensitive technique. Because the normally occurring iodine forms dissolve readily in basic solutions to form stable iodides, each of the collector components from this test were leached with $\mathrm{NH}_{4} \mathrm{OH}$ to remove this iodine for analysis. After chemical treatment of small aliquotes of the leach solution to separate the halides (especially iodine) from the other fission products, the samples were loaded onto ion-exchange media and irradiated briefly. After an optimum decay period, the samples were analyzed for the resulting $12.5-\mathrm{h}{ }^{130} \mathrm{I}$.

The iodine data, for Tests VI-6 and VI-7, are summarized in Table 3.5. The tests experienced similar time/temperature histories ( $20 \mathrm{~min}$ each at 2000 and $2300 \mathrm{~K}$ ) but were exposed to different oxidizing atmospheres. While Test VI-7 used limited steam plus air throughout the test period, Test VI-6 was heated to $2320 \mathrm{~K}$ in hydrogen, then hydrogen flow was stopped and steam was introduced later in the test. The results show that total iodine release was greater in the test with heatup in hydrogen followed by steam $(71.3 \%$ in Test VI-6) than in the test in steam + air $(41.5 \%$ in Test VI-7). Furthermore, a much larger fraction of the released iodine was retained in the furnace in pure steam $(34.2 \%$ in VI-6 vs $4.17 \%$ in VI-7).

Some iodine forms (organic iodides, elemental iodine, or hydrogen iodide) may pass through the TGTs, penetrate the filters, and adsorb onto the heated charcoal in the filter packages. For this reason. the charcoal cartridges were analyzed for ${ }^{129} 1$ by direct neutron activation also. The results of these analyses, presented in Table 3.6, show that almost all $(-98 \%)$ of this volatile iodine was collected on the first of the four cartridges during Test Phase A. The total fraction of the released iodine that was collected on the charcoal in Test VI-7 $(0.28 \%)$ was similar to most previous tests, which have averaged $<0.5 \%$. The fractions of iodine found in vapor and aerosol forms. as well as their mass ratios, are shown in Table 3.7. 
Results

Table 3.3 Physical forms of cesium released from furnace in Test VI-7

\begin{tabular}{cccc}
\hline \multirow{2}{*}{ Collection period } & \multicolumn{3}{c}{ Amount in designated form (\% or inventory) } \\
\cline { 2 - 4 } & Vapor & Aerosol & Total \\
\hline A & 24.5 & 32.7 & 57.2 \\
B & 6.6 & 10.0 & 16.6 \\
C & 12.5 & 13.8 & 26.3 \\
Total A $+B+C$ & 43.6 & 56.5 & 100 \\
\hline
\end{tabular}


Resuits

Table 3.4 Fractional releases and distributions of antimony and cobalt (from cladding) in Test VI-7 ${ }^{\circ}$

\begin{tabular}{|c|c|c|c|c|c|c|}
\hline \multirow[b]{2}{*}{ Location } & \multicolumn{3}{|c|}{${ }^{125} \mathrm{Sb}$} & \multicolumn{3}{|c|}{${ }^{60} \mathrm{Co}$} \\
\hline & $\mu \mathbf{C i}$ & $\begin{array}{c}\text { \% of } \\
\text { inventory }\end{array}$ & $\begin{array}{l}\% \text { of } \\
\text { released }\end{array}$ & $\mu \mathrm{Ci}$ & $\begin{array}{c}\% \text { of } \\
\text { inventory }\end{array}$ & $\begin{array}{c}\text { \% of } \\
\text { released }\end{array}$ \\
\hline \multicolumn{7}{|l|}{ Furnace components } \\
\hline First $\mathrm{ZrO}_{2}$ plug & 144 & 0.64 & 1.24 & 1560.0 & 19.36 & 65.00 \\
\hline Second $\mathrm{ZrO}_{2}$ plug & 5497 & 24.33 & 47.25 & 205.0 & 2.54 & 8.54 \\
\hline Exit region & 66 & 0.29 & 0.57 & 5.5 & 0.07 & 0.23 \\
\hline Furnace total & 5707 & 25.26 & 49.06 & 1770.5 & 21.97 & 73.77 \\
\hline \multicolumn{7}{|l|}{ Train A } \\
\hline TGT A & 0 & 0.00 & 0.00 & 26.0 & 0.32 & 1.08 \\
\hline TGT, filter line & 0 & 0.00 & 0.00 & 7.3 & 0.09 & 0.30 \\
\hline First pretilter & 0 & 0.00 & 0.00 & 44.3 & 0.55 & 1.85 \\
\hline Second prefillter & 0 & 0.00 & 0.00 & 0.7 & 0.01 & 0.03 \\
\hline HEPA filters & 0 & 0.00 & 0.00 & 0.0 & 0.00 & 0.00 \\
\hline Total in Train A & 0 & 0.00 & 0.00 & 78.3 & 0.97 & 3.26 \\
\hline \multicolumn{7}{|l|}{ Train B } \\
\hline TGT B & 0 & 0.00 & 0.00 & 40.0 & 0.50 & 1.67 \\
\hline TGT. filter line & 200 & 0.89 & 1.72 & 11.8 & 0.15 & 0.49 \\
\hline First pretilter & 826 & 3.66 & 7.10 & 59.4 & 0.74 & 2.48 \\
\hline Second prerilter & 50 & 0.22 & 0.43 & 4.1 & 0.05 & 0.17 \\
\hline HEPA filters & 2 & 0.01 & 0.02 & 0.2 & 0.00 & 0.01 \\
\hline Total in Train B & 1078 & +.77 & 9.27 & 115.5 & 1.43 & 4.81 \\
\hline \multicolumn{7}{|l|}{ Train C } \\
\hline TGT C & 1424 & 6.30 & 12.24 & 152.0 & 1.89 & 6.33 \\
\hline TGT. filter line & 689 & 3.05 & 5.92 & 35.1 & 0.44 & 1.46 \\
\hline First prerilter & 2620 & 11.60 & 22.52 & 237.0 & 2.94 & 9.88 \\
\hline Second prefilter & 78 & 0.35 & 0.67 & 9.8 & 0.12 & 0.41 \\
\hline HEPA tillters & 37 & 0.16 & 0.32 & 2.1 & 0.03 & 0.09 \\
\hline Total in Train C & 4848 & 21.46 & 41.67 & +36.0 & 5.41 & 18.17 \\
\hline Total released from ruei & 11633 & 51.48 & 100.00 & 2400 & 29.78 & 100.01 \\
\hline Total in ruel (after test) & 10962 & +8.52 & & 5659 & 70.22 & \\
\hline
\end{tabular}

"Inventories based on measured data: $22.595 \mu \mathrm{Ci} \stackrel{125}{ } \mathrm{Sb}$ and $8.059 \mu \mathrm{Ci}{ }^{\infty} \mathrm{Co}$. 
Results

Table 3.5 Fractional releases and distributions of iodine in Tests VI-6 and VI-7

\begin{tabular}{|c|c|c|c|c|c|c|}
\hline \multirow{2}{*}{ Location } & \multicolumn{3}{|c|}{ Test VI-6 } & \multicolumn{3}{|c|}{ Test VI-7 } \\
\hline & $\mu \mathrm{g}$ & $\begin{array}{c}\% \text { of } \\
\text { inventory }\end{array}$ & $\begin{array}{c}\% \text { of } \\
\text { released }\end{array}$ & $\mu \mathrm{g}$ & $\begin{array}{c}\% \text { of } \\
\text { inventory }\end{array}$ & $\begin{array}{l}\% \text { of } \\
\text { released }\end{array}$ \\
\hline Furnace Total & 2913 & 24.35 & 34.2 & 353 & 1.73 & 4.17 \\
\hline \multicolumn{7}{|l|}{ Train A } \\
\hline TGT A & 396 & 3.31 & 4.64 & 2031 & 9.94 & 23.9 \\
\hline TGT to filter tube & 246 & 2.06 & 2.89 & 577 & 2.82 & 6.79 \\
\hline Prefilters & 1293 & 10.81 & 15.2 & 1791 & 8.77 & 21.1 \\
\hline HEPA filters & 0 & 0.0 & 0.0 & 0 & 0.0 & 0.0 \\
\hline Charcoal & 339 & 2.83 & 3.97 & 80.2 & 0.39 & 0.94 \\
\hline Total in Train A & 2273 & 19.00 & 26.7 & 4479 & 21.9 & 52.7 \\
\hline \multicolumn{7}{|l|}{ Train B } \\
\hline TGT B & 234 & 1.96 & 2.75 & 836 & 4.09 & 9.85 \\
\hline TGT to filter tube & 18 & 0.15 & 0.21 & 160 & 0.78 & 1.88 \\
\hline Pretiliters & 177 & 1.48 & 2.08 & 543 & 2.66 & 6.41 \\
\hline HEPA fillers & 0 & 0.0 & 0.0 & 0 & 0.0 & 0.0 \\
\hline Charcoal & 64 & 0.54 & 0.75 & 0.74 & 0.004 & 0.01 \\
\hline Total in Train B & 493 & 4.12 & 5.78 & 1540 & 7.54 & 18.2 \\
\hline \multicolumn{7}{|l|}{ Train C } \\
\hline TGT C & 813 & 6.80 & 9.54 & 549 & 2.69 & 6.48 \\
\hline TGT to rilter tube & 123 & 1.03 & 1.44 & 525 & 2.57 & 6.19 \\
\hline Prefilters & 1487 & 12.43 & 17.4 & 1038 & 5.08 & 12.23 \\
\hline HEPA filters & 0 & 0.0 & 0.0 & 0 & 0.0 & 0.0 \\
\hline Charcoal & +28 & 3.58 & 5.02 & 0.96 & 0.005 & 0.01 \\
\hline Totai in Train C & 2851 & 23.83 & 33.4 & 2113 & 10.34 & 24.9 \\
\hline Total reieased from ruei & 8531 & 71.30 & & 8486 & 41.53 & \\
\hline
\end{tabular}

'Total iodine inventones based on ORIGEN2 (calculated) data: VI-6 contained $11.96 \mathrm{mg}$ and VI-7 contained $20.43 \mathrm{mg}$. 
Table 3.6 Volatile iodine collected in Test VI-7

\begin{tabular}{|c|c|c|}
\hline \multirow{2}{*}{ Sample No. } & \multicolumn{2}{|c|}{ Volatile iodine $e^{\circ}$} \\
\hline & Mass $(\mu \mathrm{g})$ & Percent of inventory \\
\hline $\mathrm{ACl}$ & 79.9 & $2.73 \mathrm{E}-1{ }^{\circ}$ \\
\hline $\mathrm{AC} 2$ & 0.186 & $6.3 E-4$ \\
\hline $\mathrm{AC3}$ & 0.071 & $2.4 E-4$ \\
\hline $\mathrm{AC} 4$ & $\mathrm{ND}^{+}$ & \\
\hline $\mathrm{BCl}$ & 0.74 & $2.5 \mathrm{E}-3$ \\
\hline $\mathrm{BC} 2$ & $\mathrm{ND}^{+}$ & \\
\hline $\mathrm{BC} 3$ & $\mathrm{ND}^{+}$ & \\
\hline $\mathrm{BC} 4$ & $\mathrm{ND}^{+}$ & \\
\hline $\mathrm{CCl}$ & 0.92 & $3.1 \mathrm{E}-3$ \\
\hline $\mathrm{CC} 2$ & 0.037 & $1.3 \mathrm{E}-4$ \\
\hline $\mathrm{CC} 3$ & $\mathrm{ND}^{+}$ & \\
\hline $\mathrm{CCA}$ & $\mathrm{ND}^{+}$ & \\
\hline Totals & 81.9 & $2.80 \mathrm{E}-1$ \\
\hline
\end{tabular}

As determined by measurements of ${ }^{129} \mathrm{I}$.

Exponential notation: $2.73 \mathrm{E}-1=2.73 \times 10^{-1}$.

${ }^{\dagger} \mathrm{ND}=$ not detected. 


\section{Resuits}

Table 3.7 Comparison of physical forms of iodine and cesium released to collection trains in Test VI-7

\begin{tabular}{|c|c|c|c|c|c|c|c|c|c|}
\hline \multirow{3}{*}{$\begin{array}{l}\text { Collection } \\
\text { period }\end{array}$} & \multicolumn{9}{|c|}{ Fraction in designated form ( $\%$ of element released from furnace) ${ }^{\circ}$} \\
\hline & \multicolumn{3}{|c|}{ Vapor } & \multicolumn{3}{|c|}{ Aerosol } & \multicolumn{3}{|c|}{ Total } \\
\hline & 1 & Cs & Cs $/ I$ & I & Cs & $\mathrm{Cs} / \mathbf{I}$ & I & Cs & $\mathbf{C s} / \mathbf{I}$ \\
\hline A & 25.9 & 24.5 & 0.95 & 29.1 & 32.7 & 1.12 & 55.1 & 57.2 & 1.04 \\
\hline $\mathrm{B}$ & 10.3 & 6.6 & 0.64 & 8.8 & 10.0 & 1.14 & 18.9 & 16.6 & 0.88 \\
\hline C & 6.8 & 12.5 & 1.84 & 19.2 & 13.8 & 0.72 & 26.0 & 26.3 & 1.01 \\
\hline Total $A+B+C$ & +3.0 & 43.6 & 1.01 & 57.1 & 56.5 & 0.99 & 100 & 100 & 1.00 \\
\hline
\end{tabular}

Based on total inventory in the ruel, $39.8 \%$ of the iodine and $4.1 \%$ of the cesium were released from the furnace. 


\subsection{Thermal Gradient Tube Deposits}

The three TGT liners were made by rolling 0.003 -in.-thick platinum foil into tubes. These liners were inserted into the surrounding Inconel TGTs and then removed after the test and examined. During the test, each of the 36-cm-long TGT liners had been subjected to maximum temperatures of $-800^{\circ} \mathrm{C}$ at the inlet end. The TGT temperatures declined approximately linearly to $-150^{\circ} \mathrm{C}$ at the exit end.

The collection of cesium on the TGT liners was monitored during the test by continuous gamma spectrometry of the ${ }^{134} \mathrm{Cs}$ and ${ }^{137} \mathrm{Cs}$. The ${ }^{137} \mathrm{Cs}$ profiles for the three TGTs, as well as the temperature profile along the TGTs, are shown in Figure 3.2. The larger amounts of ${ }^{137} \mathrm{Cs}$ in TGT A, and its concentration in the central region at deposition temperatures of 400 to $700^{\circ} \mathrm{C}$, are apparent. Small amounts of ${ }^{60} \mathrm{Co}$ (an activation product) were present in both TGT B and TGT C, and a low level of ${ }^{125} \mathrm{Sb}$ was measured in most areas of TGT C. as shown in Figure 3.3.

Upon opening the liners. the internal deposits were found to be generally gray in color and uniformly distributed. Liner B contained some thin brown deposits. but the heaviest deposits were found in Liner $C$. which was embrittled at the inlet end. Potential causes for such embrittlement of the inlet end of the platinum liner are believed to be related to alloying with elemental forms of tin (from the Zircaloy cladding) or tellurium and/or antimony (fission products), all of which had maximum release rates during Test Phase $C$.

\subsection{Masses of Deposits in TGTS and on Filters}

The filters and TGT liners were weighed betore and after the test to determine the mass of material collected. Most of the material deposited in the TGT liners is believed to be a result of vapor condensation. and the material deposited on the filters probably was transported primarily as aerosol. Immediately after disassembly of the filter packages. the filters were inspected and packaged for weighing. Although the prefilters exhibited light deposits. no deposits were visible and no weight changes were observed for the HEPA filters. indicating efficient collection of the aerosols by the pretilters.
The masses of material collected at the various locations are summarized in Table 3.8 and illustrated in Figure 3.4. As would be expected, the greatest mass was collected during Phase $C$, the highest temperature period. For similar times and temperatures, the total mass of collected material $(0.888 \mathrm{~g})$ was somewhat less in Test VI-7 than in the pure steam atmosphere Test VI-2 $(1.134 \mathrm{~g})$, but much greater than in Test VI-6 $(0.573)$, which was heated in hydrogen and then exposed to steam. The mass collected outside the furnace was $0.52 \%$ of the fuel specimen mass. As seen in previous tests in oxidizing atmospheres, the mass ratio of vapor to aerosol was about 1 to 2 .

\subsection{ICP-ES Analyses}

Samples of the acidic leach solutions from the TGT liners, the filters, and other test components were submitted for analysis by inductively coupled plasmaemission spectrometry (ICP-ES). This technique is well suited for measuring several of the non-gamma-emitting fission product elements and uranium. Unforrunately, it is not useful for iodine analysis. The high levels of radiocesium in most of the samples, however, have often required dilutions (which reduced precision) to avoid excess radiation dose to the analyst.

As would be expected, major release fractions of these less-volatile elements were retained in the outlet end of the furnace where the time (Test Phase A, B, or C) of release andior deposition cannot be determined.

Furthermore. the largest fractions of these four elements that were released to the collection trains were found in Train $\mathrm{C}$ as shown in Table 3.9. Because of its wellknown sensitivity to the effects of oxidizing conditions, most of the release of molybdenum is believed to have occurred after the cladding had been oxidized by the steam and air. Similar behavior was expected for ruthenium but is not shown by these data. (Because of the long decay time of the fuel, -14 years, more accurate analysis by gamma spectrometry for ${ }^{106} \mathrm{Ru}$ was not possible. In previous tests, gamma analysis for ${ }^{106} \mathrm{Ru}$ has indicated much lower releases of ruthenium than has the ICP method used for ruthenium in Test VI-7.)

The observed behavior of these four less-volatile fission product elements is not in consistent agreement with the CORSOR model and with other experimental data. ${ }^{18}$ The agreements for strontium and barium were reasonably good, but the indicated releases of molybdenum and 


\section{Results}

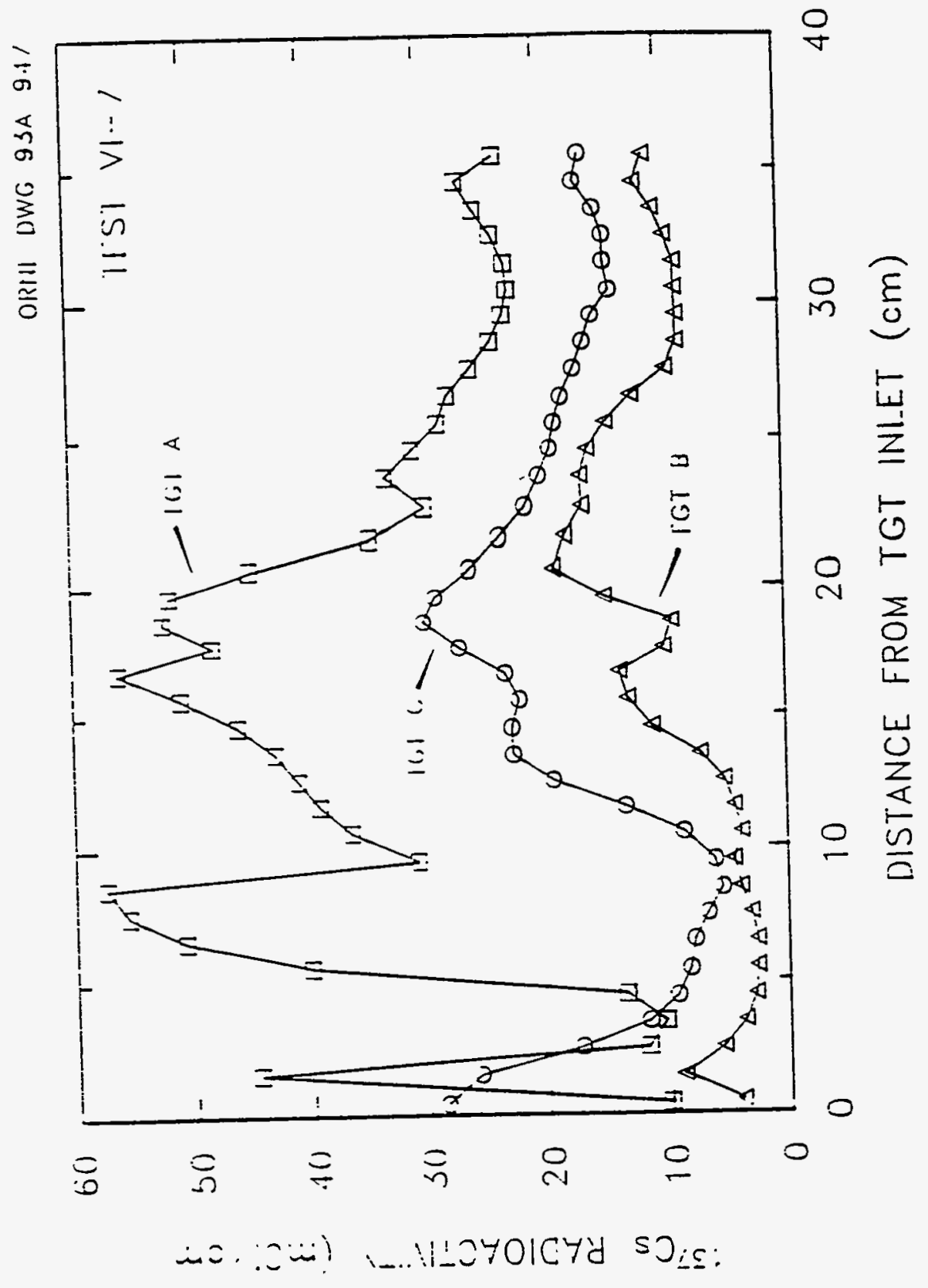

 


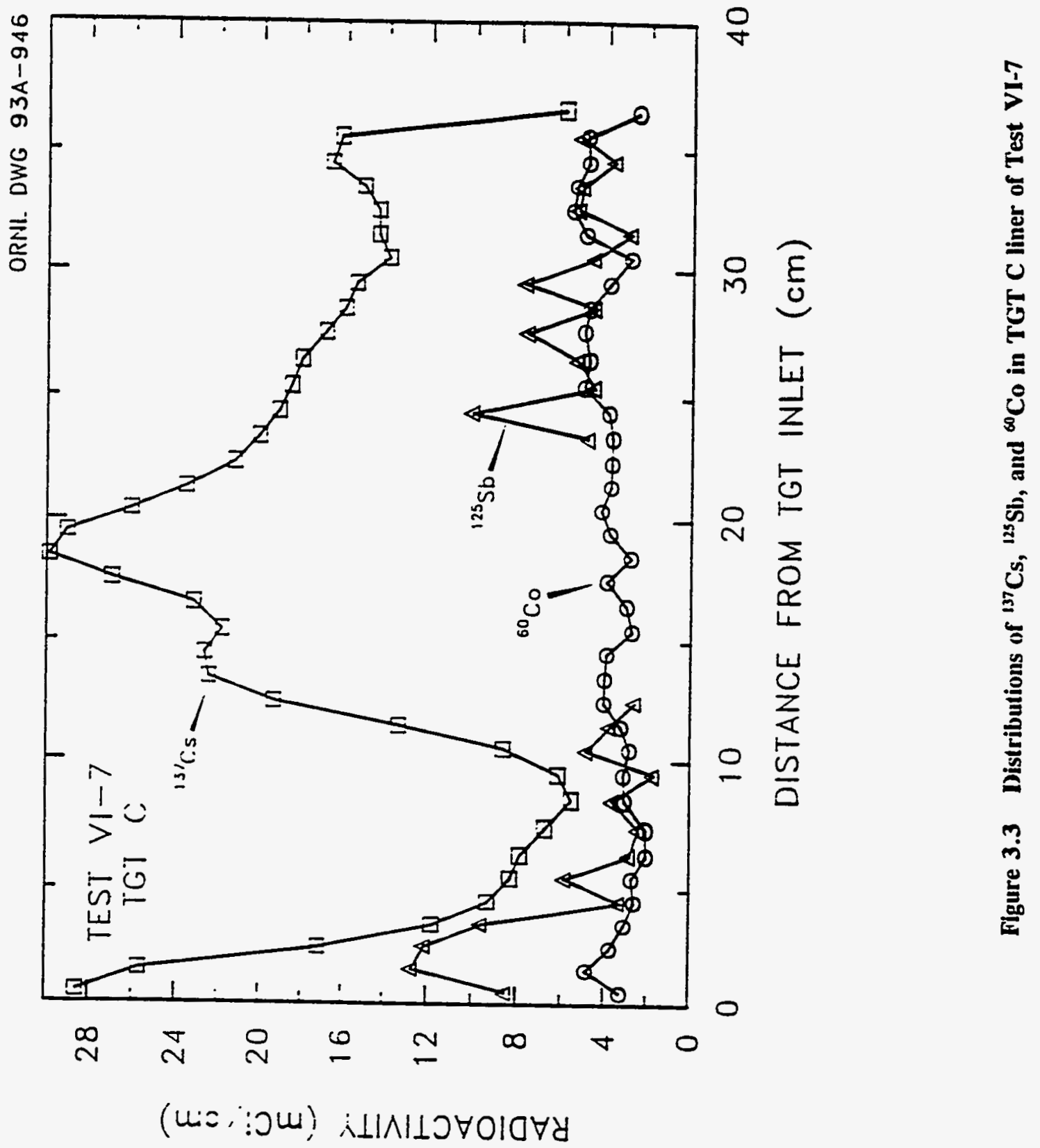




\section{Results}

Table 3.8 Vapor and aerosol deposits in Test VI-7

\begin{tabular}{lcccc}
\hline & \multicolumn{4}{c}{ Weight of deposits $(\mathbf{g})^{\circ}$} \\
\cline { 2 - 5 } & Train A & Train B & Train C & Total \\
\hline TGT & 0.108 & 0.012 & 0.206 & 0.326 \\
Filters & & & & \\
Prefilter 1 & 0.149 & 0.075 & 0.326 & 0.550 \\
Prefilter 2 & 0.004 & 0.004 & 0.004 & 0.012 \\
HEPAs & 0.000 & 0.000 & 0.000 & 0.000 \\
Total filters & 0.153 & 0.079 & 0.330 & 0.562 \\
Total deposits & 0.261 & 0.091 & 0.536 & 0.888 \\
(TGTs and filters) & & & & \\
\hline
\end{tabular}

$\cdot$ Precision $= \pm 0.003 \mathrm{~g}$. 
ORNL DWG $95 A-88$

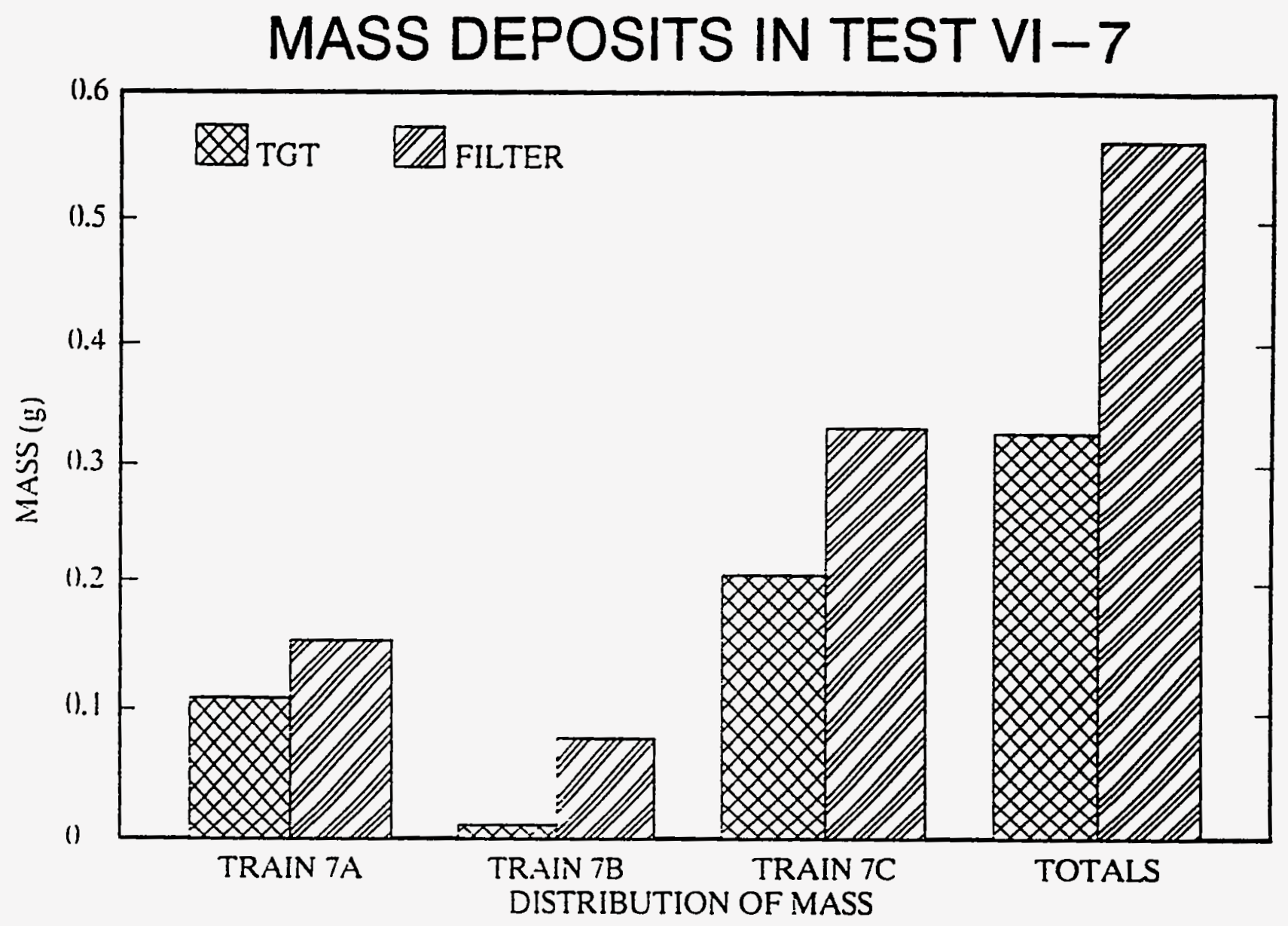

Figure 3.4 Mass distribution to the collection system of material released in Test VI-7 
Resuits

Table 3.9 Release of low-volatility fission products in Test VI-7

\begin{tabular}{lllll}
\hline & \multicolumn{4}{c}{ Fractional release from fuel (\%) } \\
\cline { 2 - 5 } $\begin{array}{l}\text { Collection } \\
\text { location }\end{array}$ & Sr & Mo & Ru* & Ba \\
\hline Furnace & 1.09 & 1.40 & 1.54 & 2.44 \\
Train A & 0.021 & 0.058 & 0.441 & 0.587 \\
Train B & 0.018 & 0.090 & 0.285 & 0.324 \\
Train C & 0.038 & 3.79 & 0.285 & 0.707 \\
Totals & 1.16 & 5.33 & 2.55 & 4.05 \\
\hline
\end{tabular}

FFul inventories were calculated by ORIGEN2.

"Values shown for ruthenium are not measured values. Although ruthenium was detected in many samples, the concentrations were not sufficient for accurate measurement. Consequentiy, we assumed $50 \%$ of the minimum quantities required for accurate measurements. 
ruthenium were much lower than expected.

Unfortunately, it was not possible to determine the extent of tellurium release. While a significant tellurium release would be expected late in the test, no tellurium was detected.

\subsection{Modeling of Volatile Fission Product Release}

Because the ${ }^{85} \mathrm{Kr},{ }^{134} \mathrm{Cs}$, and ${ }^{137} \mathrm{Cs}$ were collected and measured on line at 1-min intervals during the test, calculation of the minute-by-minute release rates was readily accomplished. As in previous tests, the release behaviors of krypton and cesium were similar.

The on-line data for krypton and cesium were used to calculate the minute-by-minute release rate and diffusion coefficients during Test VI-7. The cesium release rate coefficients, plotted as a function of temperanure during the test, are shown in Figure 3.5. The clusters of points at $2000 \mathrm{~K}$ and $2300 \mathrm{~K}$ indicate the 20 -min periods at constant temperature. It is apparent that the resulting curve lies above the CORSOR-M curve below $2000 \mathrm{~K}$ but below CORSOR-M at higher temperatures. The corresponding Test VI-7 diffusion coefficients for cesium are compared with the ORNL Booth Model in Figure 3.6. While the data deviate from the curve in the same manner (i.e., higher below $2000 \mathrm{~K}$ and lower above that temperature), the agreement with the ORNL Booth Model appears to be better than with CORSOR-MI. The cesium release rate coefficients for ail ORNL VI tests. plotted in Figure 3.7, show that Test VI-7 data lie within the envelope of data. Because the curve for the CORSOR-M model lies slightly above most ORNL-VI data. we conclude that it is conservative for cesium and other volatile fission products.

\subsection{Cladding Oxidation}

As indicated in Figure 2.1, the test atmosphere (a mixture of air, steam, and helium in Test VI-7) entered the furnace at the bottom and flowed upward past the fuel specimen. Hence, conditions were most oxidizing at the bottom end of the specimen and decreased with elevation as the oxygen in the air and the steam reacted with the hot Zircaloy cladding. In fact. during the early part of the test, all oxidizing components in the atmosphere snould have been consumed, and the steam replaced by hydrogen, before reaching the top end of the specimen.

To investigate the characteristics of the atmosphere and the extent of cladding oxidation as functions of test time and fuel specimen location, calculations were carried our using a simple model reported by Yamashita. ${ }^{19}$ In this model, oxidation of the two end caps and 11 cladding nodes in between was considered, and the results are presented in Figures 3.8 and 3.9. The vertical movement of the oxidation front along the fuel specimen is illustrated by the calculated oxidation profiles in Figure 3.8. These profiles, covering test times from 60 to $85 \mathrm{~min}$, indicate that at $60 \mathrm{~min}$ the maximum extent of cladding oxidation was $40 \%$ over the lower five cladding nodes.

The metallographic examination of two radial sections of the fuel specimen provided additional information and generally corroborated the oxidation calculations. In addition, the observations were useful in interpreting the fission product release and distribution results. One radial section from the lower end of the fuel specimen showed complete, typically uniform oxidation, as illustrated in Figure 3.10.

Some adherence of $\mathrm{UO}_{2}$ to the cladding and limited interaction is apparent at the fuel-cladding interface. A section from the upper end, while heavily oxidized, exhibited a quite different appearance (see Figure 3.11). The oxide was less uniform, with numerous voids, areas of porosity, and inclusions. suggesting that conditions changed during the test. Some mid-wall areas retained metallic phases. apparently enriched in tin driven by the oxidation front. as seen in Figure 3.12. Unidentified bright phases (Figure 3.11), believed to be zirconium nitride formed by reactions with nitrogen in the air atmosphere, were observed in many locations. The less uniform and more porous appearance of the oxidized cladding near the top end of the specimen suggested that the limited steam dominated the reaction processes and was consumed near the bottom (entrance) end, leaving a gas mixture relatively rich in air and hydrogen to react with the upper regions. In addition, the gas mixture would have changed as the oxidation front moved up the specimen, as illustrated in Figures 3.10 and 3.11. (It should be noted that the results of oxidation calculations displayed in Figures 3.8 and 3.9 assumed, based on a limited review of the literature, equal reaction rates between the cladding and the oxidizing air and steam.) 


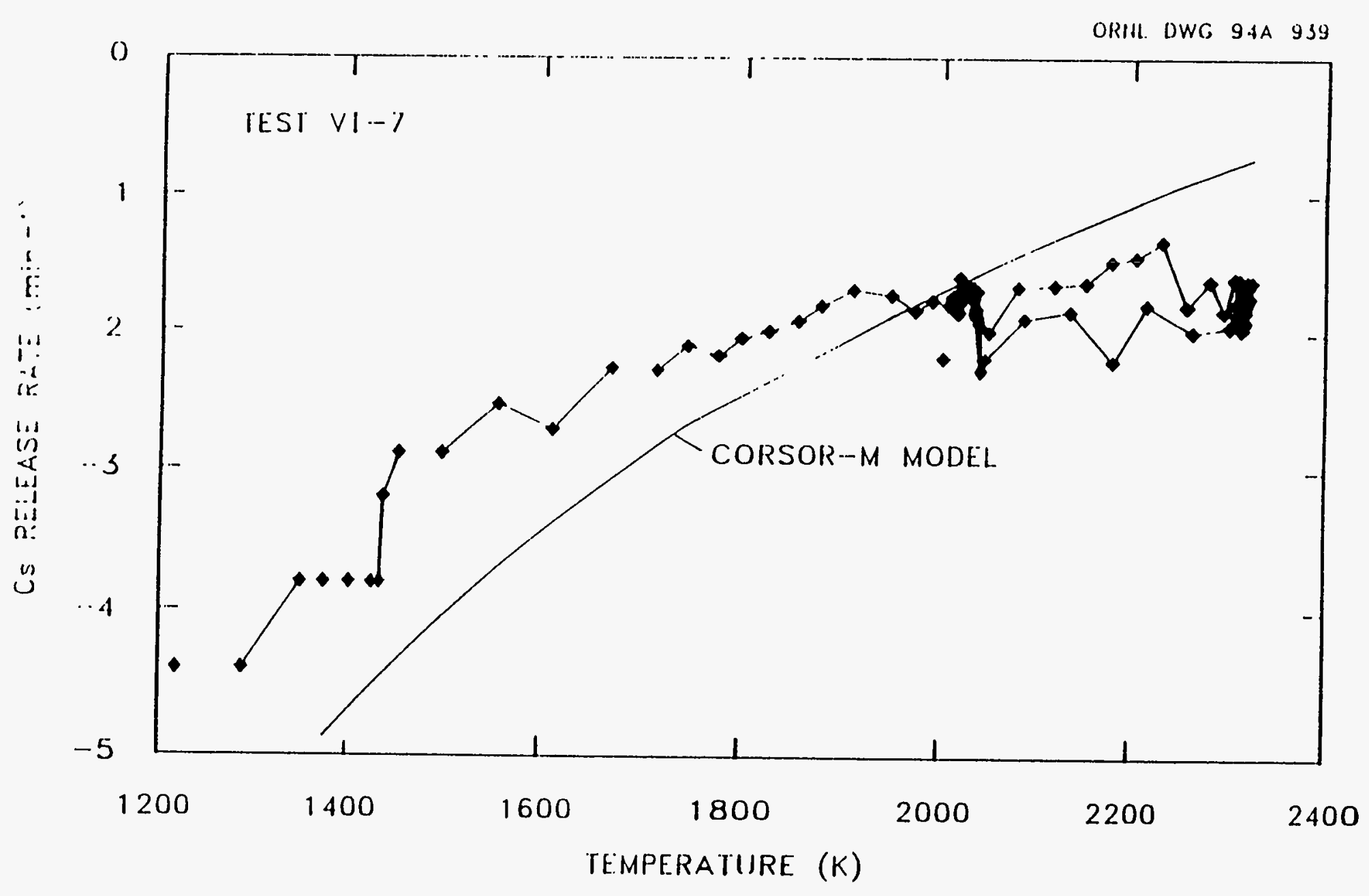

Figure 3.5 Release rate coefficients for cesium in Test VI-7, plotted as a function of temperature. Note clusters of points at 200 and $2300 \mathrm{~K}$, the periods at constant temperature. 
ORPIL DWG 94A-940

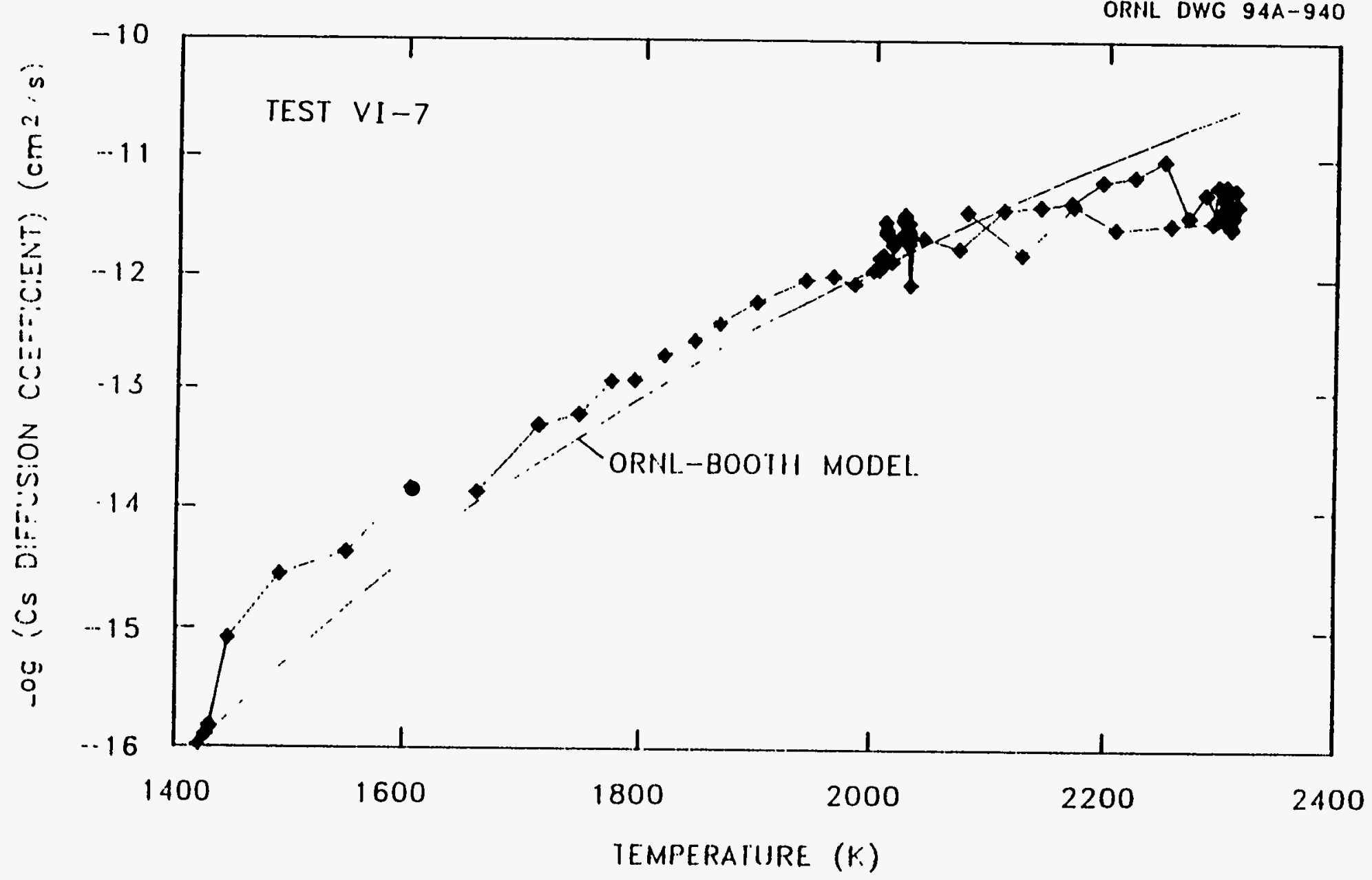

录

Figure 3.6 Diffusion coefficients for cesium release in Test VI-7. Note clusters of points at 2000 and $2300 \mathrm{~K}$, the periods at constant temperature 


\section{Resuits}

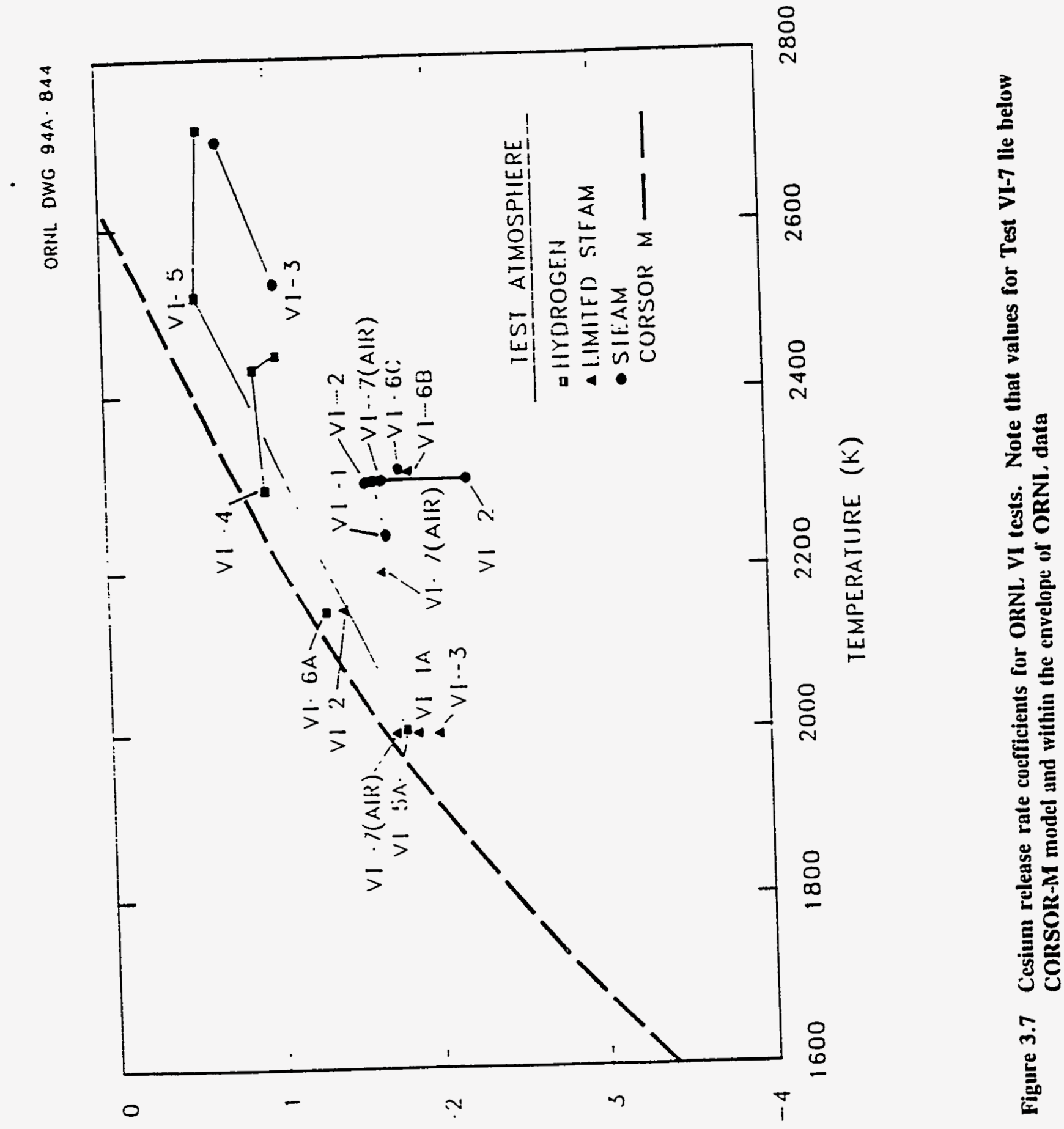




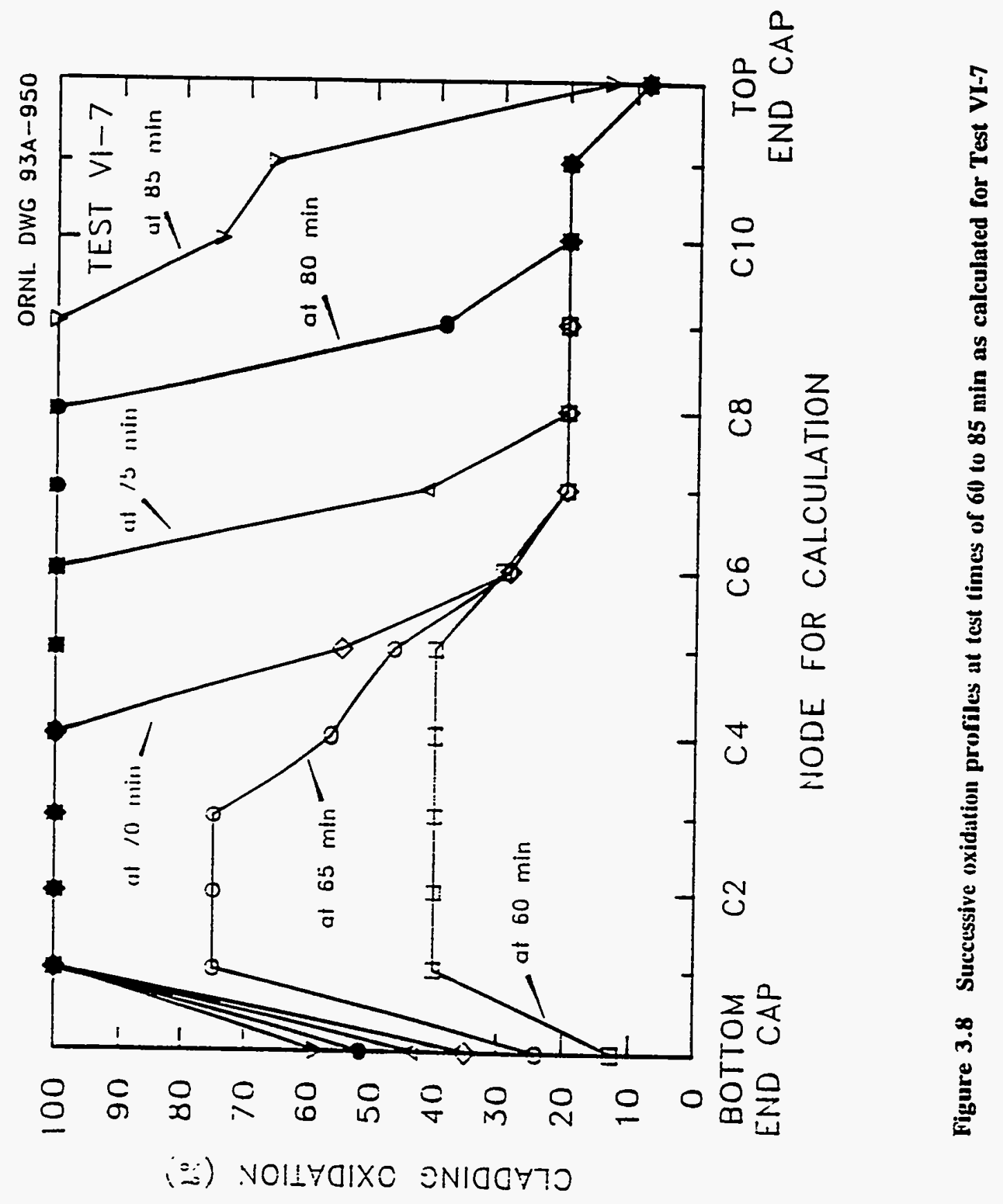




\section{Resuits}

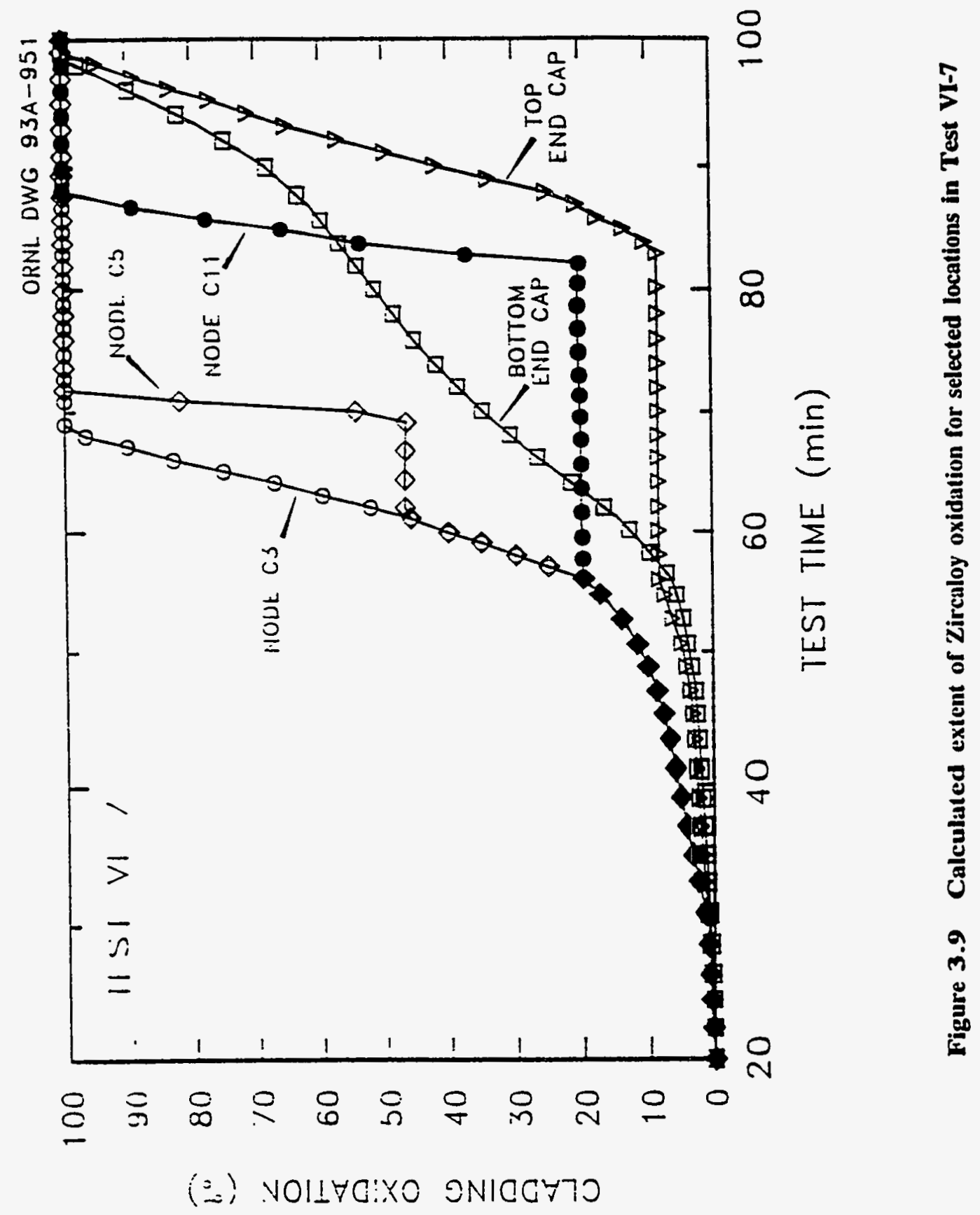



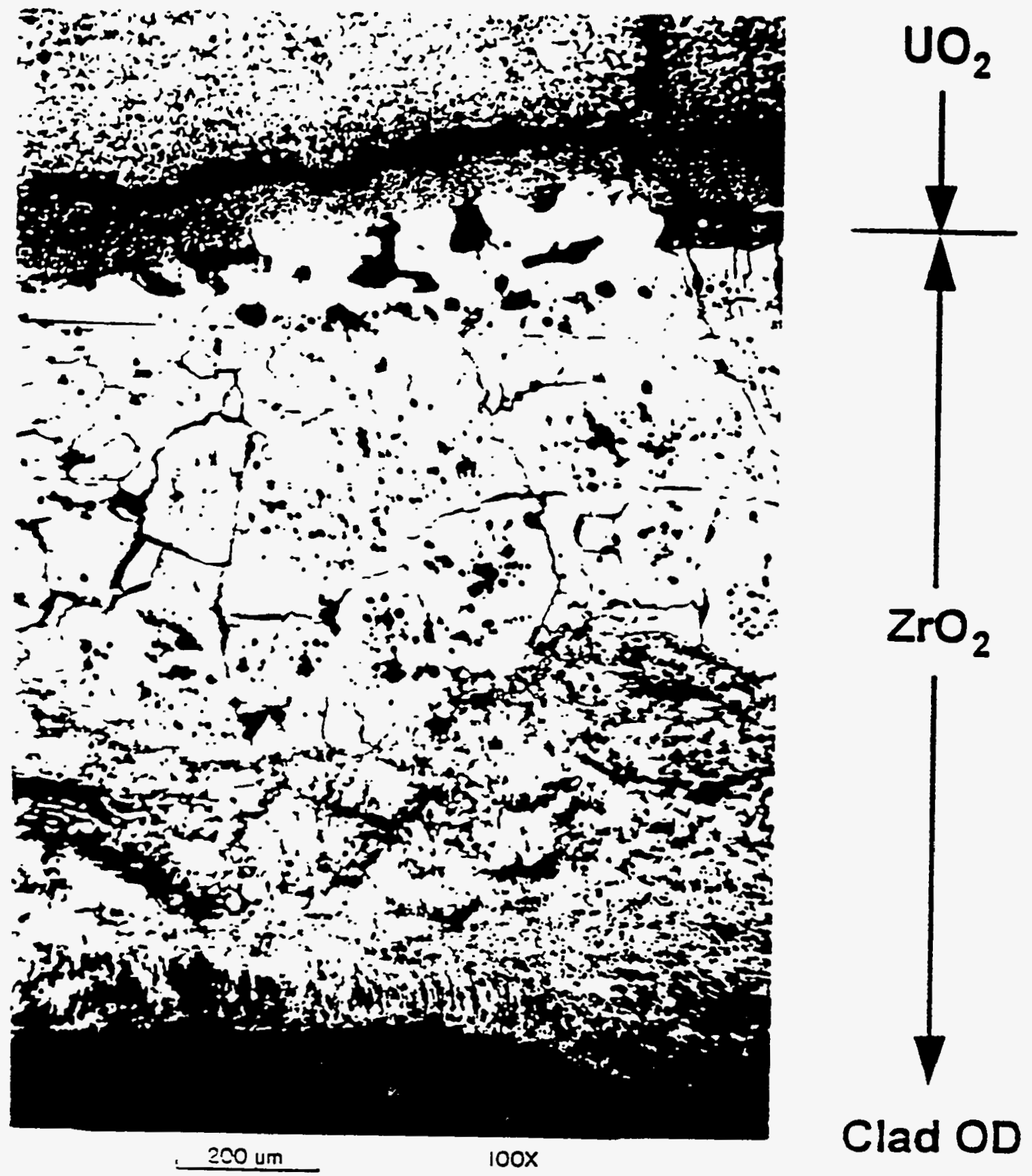

Figure 3.10 Fuel-cladding section irom near the bottom end of Test VI-7 showing uniformily oxidized cladding ana fuel-cladding interiace 
Resuits

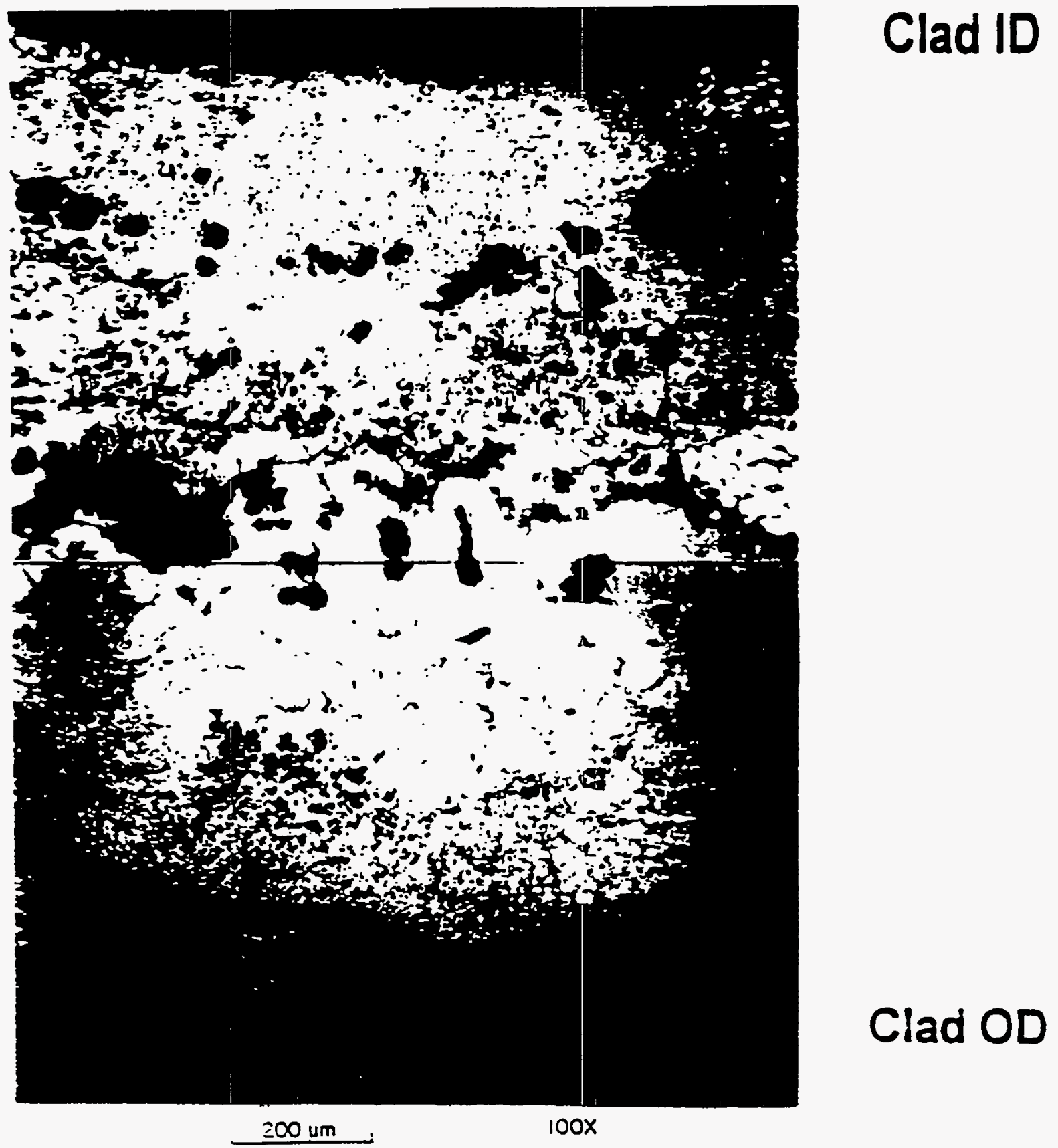

Figure 3.11 Radial section of cladding from near the top end of Test VI-7: note non-uniform oxidation, voids. und inclusions in the cladding 


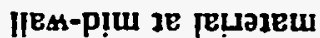

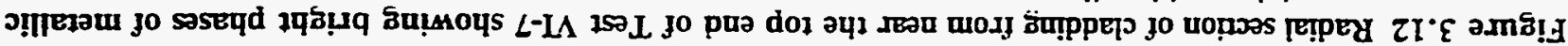

qo peio
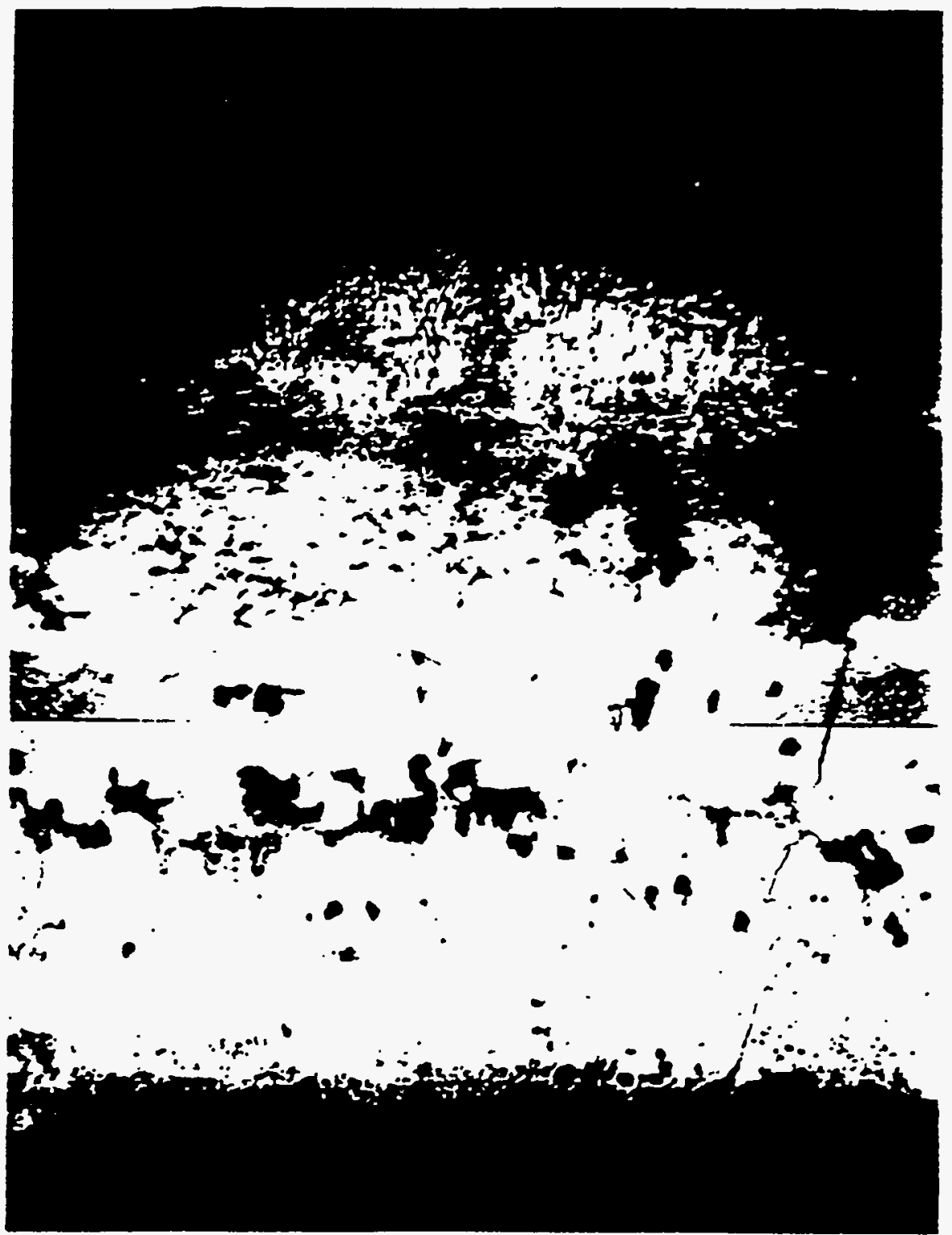


\section{Resuits}

The heavy, uniform oxide near the bottom end is typical of oxidation by steam, whereas the porous, irregular layer of oxide and other phases and inclusions near the top end suggest oxidation by air. Consequently, the $\mathrm{UO}_{2}$ fuel should have been most oxidized at the bottom end, with an oxidation gradient declining with elevation; these conditions correspond to observed release gradients along the fuel specimen for cesium and antimony (see

Figure 3.1) The good agreement of these results of metallographic examination support the predictions of the Yamashita model discussed above and verify the validity of the model. ${ }^{19}$ 


\section{Comparison of Release Data with Previous Results}

The fission product release data from Test VI-7 have been compared with the results from earlier experiments. Because it was similar to Test VI- 1 except for the addition of air into the test atmosphere, we were particularly interested in comparing the results from these two tests.

The integral release data for eight fission product elements from Test VI-7 are compared with the results from six previous tests (VI-1 through VI-6) in Table 4.1. Comparison of the data from these tests suggests that the presence of air in the atmosphere results in slightly higher releases for most elements. Moderate oxidation of the $\mathrm{UO}_{2}$ over the lower half of the specimen could explain the observed gradient in fission product release (see Figure 3.1). The indicated differences in molybdenum and ruthenium release (shown in Table 4.1) are apparent contradictions. However, the wide ranges in values for molybdenum and ruthenium release indicate relatively low levels in precision (and confidence) in the data for these elements.

On the other hand, the fractional releases of krypton and cesium were always similar, except for the lower krypton value for Test VI-2, where some of the gas was known to have been lost. Furthermore. krypton and cesium release values exhibited a general increase with test temperature, reaching $-100 \%$ at $2700 \mathrm{~K}$. No significant influence of the reactive atmospheres, steam and hydrogen, on the release of these highly volatile elements was apparent. Although the release values are somewhat lower in all cases, probably because of difficulties in complete sampling, we believe that iodine behaves similarly to krypton and cesium.

With regard to atmospheric effects on the less volatile species, the recent data supported the conclusions drawn from earlier results. ${ }^{20.21}$ The release behaviors of $\mathrm{Sb}$, $\mathrm{Mo}, \mathrm{Ba}$, and $\mathrm{Eu}$, on the other hand, showed a clear influence of the reactive atmospheres, and these atmospheric effects became more exaggerated at the highest temperature, $2700 \mathrm{~K}$. Much higher releases of $\mathrm{Sb}$ and Mo were observed in steam, whereas $\mathrm{Ba}, \mathrm{Sr}$, and Eu releases were higher in hydrogen. In conclusion, the behaviors of these elements in Test VI-7 were found to be generally consistent with their chemical characteristics and with data from previous tests.

Comparison of the total masses of material released in all VI tests. summarized in Table 4.2, shows that at $2300 \mathrm{~K}$, Test VI-7 release appears somewhat low. Test VI-1, heated at the same timeitemperature conditions, released $1.173 \mathrm{~g}$, some $32 \%$ more, or $1.2 \%$ of specimen mass vs only $0.79 \%$ of the VI-7 mass. It was not possible, unfortunately, to obtain mass spectrometric analyses for the Test VI-7 samples to determine more about the differences in composition. Comparing the ratios of TGT/filter masses (Table 4.2) shows that. in Test VI-7, a greater fraction of material was collected on the TGTs than in earlier oxidizing tests, apparently an effect of the air atmosphere. 
'I'able 4.1 Conditions and results for vertical (VI series) fission product release tests

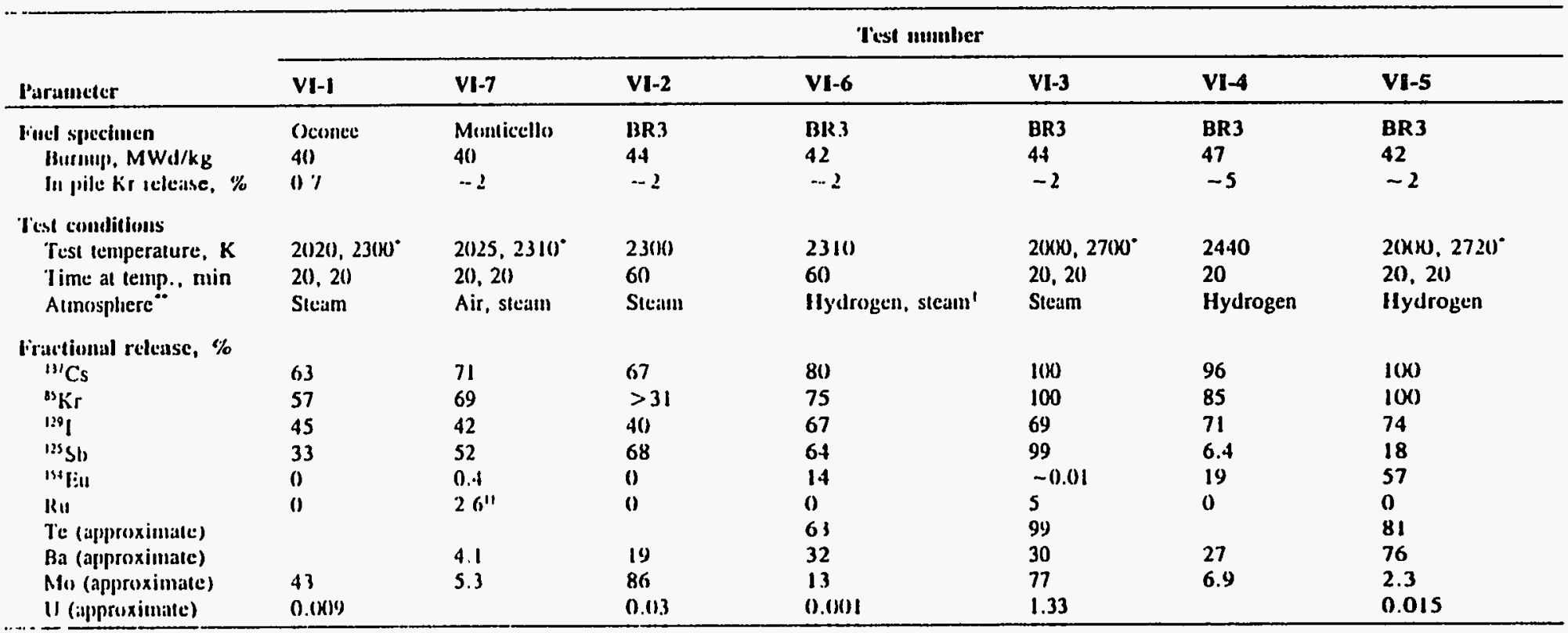

-Sume tests (VI-1, VI-3, VI.5, and VI-7) were conducted in Iwo phases at two differemt temperatures.

**All lests included lielium as a noncondensable carrier.

'Test VI.o was heated to $23(h) \mathrm{K}$ in hydrogen then switched to a steam almosphere.

"1)atid tor nuthenium release fion Test VI-7 appear to be significantly low, probably because of limited time of exposure to air. 
Comparison

Table 4.2 Mass release data for VI series tests

\begin{tabular}{|c|c|c|c|c|c|}
\hline \multirow{2}{*}{ Test phase } & \multirow{2}{*}{$\begin{array}{c}\text { Fuel } \\
\text { temperature } \\
(\mathbf{K}) \\
\end{array}$} & \multicolumn{3}{|c|}{ Mass of material collected $(\mathrm{g})^{*}$} & \multirow{2}{*}{$\begin{array}{c}\text { Ratio } \\
\text { TGT/filter }\end{array}$} \\
\hline & & TGT & Filter & Total & \\
\hline $1 \mathrm{~A}$ & 2020 & 0.078 & 0.245 & 0.323 & 0.318 \\
\hline 1B & $2020-2300$ & 0.101 & 0.227 & 0.328 & 0.445 \\
\hline $1 \mathrm{C}$ & 2300 & 0.225 & 0.297 & 0.522 & 0.758 \\
\hline Totals & & 0.404 & 0.769 & 1.173 & 0.525 \\
\hline $2 \mathrm{~A}$ & 2300 & 0.057 & 0.188 & 0.245 & 0.303 \\
\hline $2 B$ & 2300 & 0.139 & 0.434 & 0.573 & 0.320 \\
\hline $2 \mathrm{C}$ & 2300 & 0.085 & 0.231 & 0.316 & 0.368 \\
\hline Totals & & 0.281 & 0.853 & 1.134 & 0.329 \\
\hline $3 \mathrm{~A}$ & 2000 & 0.061 & 0.308 & 0.369 & 0.198 \\
\hline 3B & $2000-2700$ & 0.380 & 1.094 & 1.474 & 0.347 \\
\hline $3 \mathrm{C}$ & 2700 & 0.241 & 1.084 & 1.325 & 0.222 \\
\hline Totals & & 0.682 & 2.486 & 3.168 & 0.274 \\
\hline $4 \mathrm{~A}$ & 2440 & 0.130 & 0.072 & 0.202 & 1.806 \\
\hline $4 B$ & 2440 & 0.002 & 0.093 & 0.095 & 0.022 \\
\hline $4 C$ & 2440 & 0.029 & 0.075 & 0.104 & 0.387 \\
\hline Totals & & 0.161 & 0.240 & 0.401 & 0.671 \\
\hline $5 \mathrm{~A}$ & 2000 & 0.104 & 0.047 & 0.151 & 2.213 \\
\hline SB & $2000-2720$ & 0.050 & 0.273 & 0.323 & 0.183 \\
\hline $5 \mathrm{C}$ & 2720 & 0.030 & 0.177 & 0.207 & 0.169 \\
\hline Totals & & 0.184 & 0.497 & 0.681 & 0.370 \\
\hline $6 \mathrm{~A}$ & 2310 & 0.100 & 0.036 & 0.136 & 2.778 \\
\hline $6 B$ & 2310 & 0.031 & 0.015 & 0.046 & 2.067 \\
\hline $6 C$ & 2310 & 0.161 & 0.230 & 0.391 & 0.700 \\
\hline Totals & & 0.292 & 0.281 & 0.573 & 1.039 \\
\hline $7 \mathrm{~A}$ & 2025 & 0.108 & 0.153 & 0.261 & 0.706 \\
\hline $7 \mathrm{~B}$ & $2025-2310$ & 0.012 & 0.079 & 0.091 & 0.152 \\
\hline $7 \mathrm{C}$ & 2310 & 0.206 & 0.330 & 0.536 & 0.624 \\
\hline Totals & & 0.326 & 0.562 & 0.888 & 0.580 \\
\hline
\end{tabular}

*Precision $= \pm 0.003 \mathrm{~g}$. 


\section{Summary}

\section{Summary and Conclusions}

This report summarizes all information available for Test VI-7 and compares the results with previous tests in this series. More extensive comparison and interpretation of all results are available. ${ }^{8.13}$

1. This was the first test in the VI series to include air in the test atmosphere. As expected, the mixture of air and limited steam caused complete oxidation of the Zircaloy cladding, and probably some oxidation of the $\mathrm{UO}_{2}$ fuel near the inlet end. Near the outlet end of the fuel specimen, however, the cladding oxidation was extensive but not complete.

2. The measured integral release values for the fission products in this test were $69 \%$ for ${ }^{85} \mathrm{Kr}, 42 \%$ for ${ }^{129} \mathrm{I}, 71 \%$ for ${ }^{137} \mathrm{Cs}, 52 \%$ for ${ }^{125} \mathrm{Sb}, 0.40 \%$ for ${ }^{154} \mathrm{Eu}$, $1.2 \%$ for $\mathrm{Sr},>2.6 \%$ for $\mathrm{Ru}, 4.1 \%$ for $\mathrm{Ba}$, and $5.3 \%$ for Mo. Comparison of these results with data from previous tests indicated generaliy consistent behavior. Except for molybdenum and ruthenium, slightly greater releases were observed in air + steam (than in steam) at similar times and temperatures.

3. Fission product retention in the furnace varied widely. The retention fractions for cesium and iodine were fairly typical of previous tests: $10.4 \%$ for cesium and $4.2 \%$ for iodine. The retention of antimony, however, was $49 \%$ higher than was found in the steam oxidizing tests VI-1 through VI-3.
4. The total mass of deposits collected on the TGTs and the filters $(0.888 \mathrm{~g})$ was somewhat less than in other oxidizing tests at this temperature $(2300 \mathrm{~K})$.

5. Approximately $0.25 \%$ of the released iodine was collected on the charcoal filter cartridges, indicating it had been in a volatile form $-\mathrm{I}_{2}, \mathrm{HI}$, and/or $\mathrm{CH}_{3}$ I. This fraction is similar to values found for most of the VI tests; only VI-5 and VI-6 had a larger fraction of the released iodine in the charcoal.

6. The fractional releases of several less-volatile fission product elements were found to be significant, varying from $1.2 \%$ for strontium to $5.3 \%$ for molybdenum.

7. As in all previous tests, the release behavior of the volatile species (krypton and cesium) was very similar in Test VI-7. In addition, the diffusion coefficients for krypton and cesium calculated from on-line release data were in good agreement with the ORNL-Booth Model.

8. Metallographic examination of two radial sections from the fuel specimen verified that conditions had been somewhat more oxidizing at the bottom (inlet) end than at the top. In addition, the results indicated that calculations by a previously developed cladding oxidation model described the oxidation sequence with reasonable accuracy. 


\section{References}

1. Osborne, M. F., J. L. Collins, and R. A. Lorenz, "Experimental Studies of Fission Product Release from Commercial LWR Fuel Under Accident Conditions," Nucl. Technol. 78(2):157-69 (August 1987).

2. Osborne, M. F., J. L. Collins, R. A. Lorenz, J. R. Travis, C. S. Webster, and T. Yamashita, "Data Summary Report for Fission Product Release Test VI-1," NUREG/CR-5339 (ORNL/TM-11104), June 1989.

3. Osborne, M. F., J. L. Collins, R. A. Lorenz, J. R. Travis, and C. S. Webster, "Data Summary Report for Fission Product release Test VI-2,"

NUREG/CR-5340 (ORNL/TM-11105), September 1989.

4. Osborne, M. F., J. L. Collins, R. A. Lorenz, J. R. Travis, C. S. Webster, S. R. Daish, H. K. Lee, T. Nakamura, and Y.-C. Tong, "Highlights Report for Fission Product Release Test VI-3," draft letter report to SFD Partners, July 1987.

5. Osborne, M. F., R. A. Lorenz, J. L. Collins, J. R. Travis, C. S. Webster, and T. Nakamura. "Data Summary Report for Fission Product Release Test VI-4," NUREG/CR-5481 (ORNL/TM-11400), January 1991.

6. Osborne, M. F., R. A. Lorenz. J. R. Travis. C. S. Webster, and J. L. Collins. 'Data Summary Report for Fission Product Release Test VI-5, " ORNL/CR5668 (ORNL/TM-11743), October 1991.

7. Osborne, M. F., R. A. Lorenz. J. R. Travis, C. S. Webster, and C. S. Lee, "Preliminary Resuits from ORNL Fission Product Release Test VI-6." ORNL/NRC/LTR-91/19 (drart), September 1991.

8. Osborne, M. F., and R. A. Lorenz, "ORNL Studies of Fission Product Release Under LWR Accident Conditions." Nuclear Safety 33(3):344-65, July-Sept. 1992.

9. Osborne, M. F.. and R. A. Lorenz. "Fission Product Release at Severe Accident Conditions:
FY 1989 Program Plan," ORNL/NRC/LTR-89/2, April 1989.

10. Lorenz, R. A., J. L. Collins, and S. R. Manning, "Fission Product Release from Simulated LWR Fuel," NUREG/CR-0274 (ORNL/TM-154), October 1978.

11. Albrecht, H., "Freisetzung von Spali- und Aktivienungsprodukten beim LWR-Kernschmelzen: Abschlussbericht des SASCHA-Programmes (Translation: Release of Fission and Activation Products During LWR Core Melting: Final Report of the SASCHA Program), " Report KfK 4264, Kernforschungszentrum Karlsruhe, Germany, June 1987.

12. Osborne, M. F., J. L. Collins, P. A. Haas, R. A. Lorenz. J. R. Travis, and C. S. Webster, "Design and Final Safety Analysis Report for Vertical Furnace Fission Product Release Apparatus in Hot Cell B, Building 4501," NUREG/CR-4332, ORNL/TM-9720, March 1986.

13. Lorenz, R. A., and M. F. Osborne, "A Summary of ORNL Fission Product Release Tests with Recommended Release Rates and Diffusion Coefficients." NUREG/CR-6261, ORNL/TM12801. draft December 1994, in publication.

14. Pasupathi, V., L. M. Lowry, and M. C. Matthews, "Postirradiation Examination of Fuel Rods from the Monticello Reactor," BCL-585-82-2, June 1982.

15. Croff. A. G., "ORIGEN2 - A Revised and Updated Version of the Oak Ridge Isotope Generation and Depletion Code," ORNL-5621, July 1980.

16. Lorenz. R. A., et al., Prompt Release of Fission Products from Zircaloy-Clad $\mathrm{UO}_{2}$ Fuels, Section 1 in "Nuclear Safety Program Annual Progress Report for the Period Ending December 31, 1967," ORNL-4228, April 1968. 
17. Collins, J. L., M. F. Osborne, R. A. Lorenz, and A. P. Malinauskas, "Fission Product Iodine and Cesium Release Behavior Under Severe LWR Accident Conditions," Nucl. Technol. 81(10):78-94 (1987).

18. Kuhiman, M. R., D. J. Lehmicke, and R. O. Meyer, "CORSOR User's Manual," NUREG/CR4173 (BMI-2122), March 1985.

19. Toshiyuki Yamashita, "Steam Oxidation of Zircaloy Cladding in the ORNL Fission Product Release Tests," NUREG/CR-4777 (ORNL/TM-10272), March 1988.
20. M. F. Osborne, R. A. Lorenz, and J. L. Collins, "Atmospheric Effects on Fission Product Behavior at Severe Accident Conditions," in Proc. Am. Nucl. Soc. Int $\%$. Top. Mig. on the Safety of Thermal Reactors, Portiand, OR, July 21-25, 1991.

21. M. F. Osborne and R. A. Lorenz, "Results of ORNL VI Series Fission Product Release Tests," in Proceedings of Twentieth Water Reactor Safety Information Meeting, Bethesda, MD, October 21-23, 1992. 
NUREG/CR-6318

ORNL/TM-12937

Dist. Category R3

\section{INTERNAL DISTRIBUTION}

$\begin{aligned} \text { 1. } & \text { K. K. Anderson } \\ 2 . & \text { F. Barrera } \\ \text { 3-7. } & \text { E. C. Beahm } \\ \text { 8. } & \text { A. Boatman } \\ 9 . & \text { M. W. Burden } \\ \text { 10. } & \text { C. W. Chase } \\ \text { 11. } & \text { J. L. Collins } \\ \text { 12. } & \text { T. A. Dillow } \\ \text { 13. } & \text { B. Z. Egan } \\ \text { 14. } & \text { W. A. Gabbard } \\ \text { 15. } & \text { S. R. Greene } \\ \text { 16. } & \text { D. D. Lee } \\ \text { 17. } & \text { A. P. Malinauskas } \\ \text { 18. } & \text { L. E. McNeese } \\ \text { 19. } & \text { G. W. Parker }\end{aligned}$

20. J. C. Rudolph

21. R. R. Shoun

22. B. B. Spencer

23. R. P. Taleyarkhan

24. J. R. Travis

25. R. J. Weaver

26. C. S. Webster

27. A. L. Wright

28. Central Research Library

29. ORNL-Y-12 Technical Library

Document Reference Section

30-31. Laboratory Records

32. Laboratory Records, ORNL RC

33. ORNL Patent Section

\section{EXTERNAL DISTRIBUTION}

34. Office of Assistant Manager for Energy Research and Development, ORO-DOE, P.O. Box 2001, Oak Ridge, TN 37831

35. Director, Division of Reactor Safety Research, U.S. Nuclear Regulatory Commission, Washington, DC 20555

36-37. Office of Scientific and Technical Information, P.O. Box 2001, Oak Ridge, TN 37831

38. B. Andre, Centre d'Etudes Nucleáires de Grenoble, DTP/SECC, 17 Rue des Martyrs, 38054 Grenoble Cedex 9, France

39. J. Bagues, Consejo de Seguridad Nuckan, SOR Angela de la Cruz No 3, Madrid 28056, Spain

40-41. A. Behbahani, Accident Evaluation Branch, U.S. Nuclear Regulatory Commission, Mail Stop T-10-K-8, Washington, DC 20555

42. N. Bixler, Sandia National Laboratory, P.O. Box 5800, Albuquerque, NM 87185

43. B. R. Bowsher, AEA Technology, Winfrith, Dorchester, Dorset DT2 8DH, United Kingdom

44. K. J. Brinkman, Reactor Centrum Nederland, 1755 ZG Petten, The Netherlands

45. M. L. Brown, 15 Barrock St., Thurso Caithness, Scotland KW14 7DB

46. I. Catton, University of California Los Angeles, Nuclear Energy Laboratory, 405 Hilgard Avenue, Los Angeles, CA 90024

47. D. S. Cox, Chalk River Laboratories, Chalk River, Ontario, Canada KOJ 1JO

48. S. Hagen, Bau 601, Kernforschungszentrum Karlsruhe, Postface 3640, D7500 Karlsruhe 1, Germany

49. R. J. Hammersley, Fauske and Associates, Inc., 16WD70 West 83rd Street, Burr Ridge, IL 60521

50. R. R. Hobbins, P.O. Box 971, Wilson, WY 83014

51. F. C. Inglesias, AECL, Chalk River Nuclear Laboratories, Chalk River, Ontario, KOJ 1JO, Canada

52. S. Kinnersly, UKAEA, Winfrith, Dorchester DT2-8DH, Dorset, England

53. H. K. Lee, Spent Fuel Storage and Disposal Technology Section, Korea Advanced Energy Research Institute, P.O. Office Box 7, Dae-Danji Choong-Nam, Republic of Korea

54. R. Y. Lee, U.S. Nuclear Regulatory Commission, Office of Nuclear Regulatory Research, Mail Stop T-10-K-8, Washington, DC 20555 
55. J. Leveque, Cadarache Center for Nuclear Studies, F-13108 Saint Paul-Lez Durance Cedex, France

56. B. J. Lewis, Centre d'Etudes Nucleáires de Grenoble, DTP/SECC, 17 Rue des Martyrs, 38054 Grenoble Cedex 9, France

57. Y. Y. Liu, Argonne National Laboratory, 9700 South Cass Ave., Argonne, IL 60439

58. D. Lorenz, Rt. 3, Box 314-AA, Oliver Springs, TN 37840

59. T. Nakamura, DRS/SEMAR/LPA/JAERI, CEN Cadarache, 13108 St. Paul-lez-Durance, France

60. L. A. Neimark, Argonne National Laboratory, 9700 South Cass Ave., Argonne, IL 60439

61. A. Nichols, Technology Division, AEE Winfrith, Dorchester, Dorset, England

62. K. S. Norwood, Nuclear Electric plc, Bridgwater Road, Bedminister Down, Bristol BS13 8AN, England

63-67. M. Osborne, 123 Baltimore Drive, Oak Ridge, TN 37830

68. D. J. Osetek, Los Alamos Technical Associates, Inc., 2400 Louisiana Blvd. N.E., Building 1, Suite 400, Albuquerque, NM 87110.

69. R. L. Palla, Jr., U.S. Nuclear Regulatory Commission, Office of Nuclear Regulatory Research, OWFN 10 E 4, Washington, DC 20555

70. D. A. Petti, EG\&G Idaho, Inc., P.O. Box 1625, Idaho Falls, ID 83401

71. T. Pratt, Brookhaven National Laboratory, 130 BNL, Upton, NY 11973

72. K. O. Reil, Sandia National Laboratory, P.O. Box 5800, Albuquerque, NM 87185

73. J. Rest, Argonne National Laboratory, 9700 South Cass Ave., Argonne, IL 60439

74. L. A. Simpson, Whiteshell Laboratories AECL Research, Reactor Safety Research Division, Pinawa, Manitoba, Canada ROE 1LO

75. L. Soffer, U.S. Nuclear Regulatory Commission, Office of Nuclear Reactor Regulation, Mail Stop T-10-K-8, Washington, DC 20555

76. K. Y. Suh, Fauske \& Associates, Inc., 16W070 West 83rd St., Burr Ridge, IL 60521

77. Kenji Takumi, Nuclear Power Engineering Center, Fujitakanko Building, 17-1, 3-Chrome, Toranomon, Minato$\mathrm{Ku}$, Tokyo 105, Japan

78. A. C. Thadani, U.S. Nuclear Regulatory Commission, Office of Nuclear Reactor Regulation, OWFN 8E2, Washington, DC 20555

79. S. Thompson, Sandia National Laboratory, P.O. Box 5800, Albuquerque, NM 87185

80. Y.C. Tong, Institute of Nuclear Energy Research, P.O. Box 3-6, Lung-Tan, Taiwan, Republic of China

81. P. Vaisnys, VATESI, Gediminis Prospect 36, Vilnius, Lithuania

82. K. Washington, Sandia National Laboratory, P.O. Box 5800, Albuquerque, NM 87185

83. D. Williams, UKAEA, Winfrith, Dorchester DT2-8DH, Dorset, England

84. S. J. Wisbey, B.220, AERE Harwell, Didcot, Oxon OX11 ORA, United Kingdom

85. J. W. Wolfe, Westinghouse Bettis Atomic Laboratory, P.O. Box 79, ZAP 34N, West Mifflin, PA 15122

86. T. Yamashita, Nuclear Fuel Chemistry Laboratory, Department of Chemistry, Japan Atomic Energy Research Institute, Tokai-mura, Naka-gun, Ibaraki-ken, 319-11, Japan

87-176. Given distribution as shown in Category R3 (NTIS - 10) 


\begin{tabular}{|c|c|}
\hline $\begin{array}{l}\text { U.S. NUCLEAR REGULATORY COMMISSION } \\
\text { BIBLIOGRAPHIC DATA SHEET } \\
\text { (See instructions on the reverse) }\end{array}$ & $\begin{array}{l}\text { 1. REPORT NUMBER } \\
\text { (Ausigned by NRCE Add Vol. Supp.. Rev... } \\
\text { and Addendum Numbers, if anv.) } \\
\text { NUREG/CR-6318 }\end{array}$ \\
\hline \multirow[t]{2}{*}{ 2. TITLE AND SUBTITLE } & ORNL/TM-12937 \\
\hline & DATE REPORT PUBLISHED \\
\hline \multirow[t]{2}{*}{ Data Summary Report for Fission Product Release Test VI-7 } & \begin{tabular}{|c|r|} 
MONTH & VEÄत्र \\
May & 1995 \\
\end{tabular} \\
\hline & $\begin{array}{l}\text { 4. FIN OR GRANT NUMBER } \\
\text { L2250 }\end{array}$ \\
\hline $\begin{array}{l}\text { 5. AUTHOR(S) } \\
\text { M. F. Osborne, R. A. Lorenz, J. R. Travis, J. L. Collins, and }\end{array}$ & $\begin{array}{l}\text { 6. TYPE OF REPORT } \\
\text { Technical }\end{array}$ \\
\hline $\begin{array}{l}\text { M. F. Osborne, R. A. Lorenz, J. R. Travis, J. L. Collins, and } \\
\text { C. S. Webster }\end{array}$ & 7. PERIOD COVERED IIntlusive Oares. \\
\hline
\end{tabular}

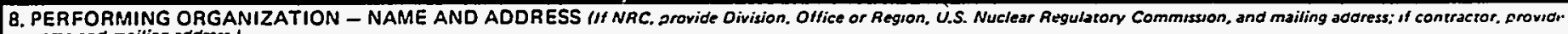
name and mailing eddress)

Oak Ridge National Laboratory

Martin Marietta Energy Systems, Inc.

P.O. Box 2008

Oak Ridge Tennessee 37831-6221

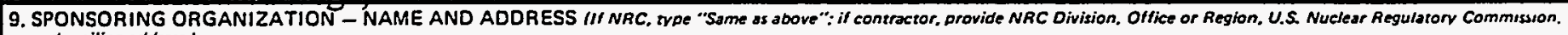
and mailing address.)

Division of Systems Research

Office of Nuclear Regulatory Research

U. S. Nuclear Regulatory Commission

Washington. D.C 20555

10. SUPPLEMENTAAY NOTES

11. ABSTRACT (200 words or less)

Test VI-7 was the final test in the VI series conducted in the vertical furnace. The fuel specimen was a 15.2-cm-long section of a fuel rod from the Monticello boiling water reactor (BWR). The fuel had experienced a burnup of $\sim 40 \mathrm{Mwd} / \mathrm{kg} \mathrm{U}$. It was heated in an induction furnace for successive 20 -min periods at 2000 and $2300 \mathrm{~K}$ in a moist air-helium atmosphere.

Integral releases were $69 \%$ for $85 \mathrm{Kr}, 52 \%$ for ${ }^{125} \mathrm{Sb}, 71 \%$ for both ${ }^{134} \mathrm{Cs}$ and ${ }^{137} \mathrm{Cs}$, and $0.04 \%$ for ${ }^{154} \mathrm{Eu}$. For the non-gamma-emitting species, release values for $42 \%$ for I, $4.1 \%$ for $\mathrm{Ba}, 5.3 \%$ for $\mathrm{Mo}$, and $1.2 \%$ for $\mathrm{Sr}$ were determined. The total mass released from the furnace to the collection system, including fission products, fuel, and structural materials, was $0.89 \mathrm{~g}$, with $37 \%$ being collected on the thermal gradient tubes and $63 \%$ downstream on filters. Posttest examination of the fuel specimen indicated that most of the cladding was completely oxidized to $\mathrm{ZrO}_{2}$, but that oxidation was not quite complete at the upper end. The release behaviors for the most volatile elements, $\mathrm{Kr}$ and Cs, were in good agreement with the ORNL-Booth Model.

\begin{tabular}{l} 
13. AVAILABILITY STATEMEINT \\
Unlimited \\
\hline 14. SECURITY CLASSIFICATION \\
(This Page) \\
Unclassified \\
(This Report \\
Unclassified \\
\hline 15. NUMBER OF PAGES \\
\hline 16. PRICE
\end{tabular}

Fission product

Fission product release

Fuel damage 